\title{
White Wine Protein Instability: Mechanism, Quality Control and Technological Alternatives for Wine Stabilisation-An Overview
}

\author{
Fernanda Cosme ${ }^{1, *(\mathbb{0}}$, Conceição Fernandes ${ }^{2}$, Tânia Ribeiro ${ }^{1}$, Luís Filipe-Ribeiro ${ }^{1}[$ and \\ Fernando M. Nunes ${ }^{1}(\mathbb{D}$ \\ 1 CQ-VR, Chemistry Research Centre-Vila Real, Food and Wine Chemistry Lab., School of Life Sciences and \\ Environment, University of Trás-os-Montes and Alto Douro, 5000-801 Vila Real, Portugal; \\ tania.im.ribeiro@gmail.com (T.R.); fmota@utad.pt (L.F.-R.); fnunes@utad.pt (F.M.N.) \\ 2 Centro de Investigação de Montanha (CIMO), ESA-Polytechnic Institute of Bragança, Campus de Santa \\ Apolónia, 5300-253 Bragança, Portugal; conceicao.fernandes@ipb.pt \\ * Correspondence: fcosme@utad.pt; Tel.: +351-259-350-000
}

Received: 7 January 2020; Accepted: 9 March 2020; Published: 17 March 2020

\begin{abstract}
Wine protein instability depends on several factors, but wine grape proteins are the main haze factors, being mainly caused by pathogenesis-related proteins (thaumatin-like proteins and chitinases) with a molecular weight between $10 \sim 40 \mathrm{kDa}$ and an isoelectric point below six. Wine protein stability tests are needed for the routine control of this wine instability, and to select the best technological approach to remove the unstable proteins. The heat test is the most used, with good correlation with the natural proteins' precipitations and because high temperatures are the main protein instability factor after wine bottling. Many products and technological solutions have been studied in recent years; however, sodium bentonite is still the most efficient and used treatment to remove unstable proteins from white wines. This overview resumes and discusses the different aspects involved in wine protein instability, from the wine protein instability mechanisms, the protein stability tests used, and technological alternatives available to stabilise wines with protein instability problems.
\end{abstract}

Keywords: wine protein; wine haze; pathogenesis-related proteins; protein stability tests; protein stability treatments

\section{Introduction}

Proteins exist in wine at low levels, related to the protein content and composition of the grapes, which are also dependent on the grape variety and maturation conditions, as well as on the winemaking process [1]. Proteins can be responsible for a wine colloidal instability, forming amorphous sediment or flocculate, and produce a suspended and undesirable haze before or after bottling [1-5] that can cause serious economic losses to the wine producers. This instability is more important in white wines, as white wine limpidity is an essential sensory quality parameter. Wine protein haze formation can occur under high temperatures, throughout storage or wine transportation due to the protein self-aggregation phenomena, resulting in light-dispersing particles [6,7]. The formation of wine protein haze is a multifactorial process with several factors known to influence the process, such as storage or wine ageing temperature, $\mathrm{pH}$, ionic strength, wine protein composition, organic acids, ethanol, phenolic compounds, metals and sulphate content; however, other important factors remain unidentified, such as the non-proteinaceous component(s) usually named $X$ factor [8-12]. Protein instability can also occur via the blending of stable wines. The haze formation does not constitute a health risk to consumers [13] or affect the olfactory and gustatory wine characteristics $[9,14]$; however, 
the formation of haze or deposits in bottled wines can affect their commercial presentation, making them unacceptable for consumers due to the visual aspect [1,15].

The most important proteins that have been related to wine protein instability are pathogenesis-related proteins of Vitis vinifera that include the chitinases and thaumatin-like proteins $[2,16]$. These proteins can be slowly denatured and aggregate throughout wine storage, forming a light-dispersing haze [17]; therefore, this phenomenon needs to be prevented by removing them from the wine, usually by fining, before wine bottling [13].

Protein instability is presently prevented by the elimination of unstable proteins from the wine using specific fining agents. Fining agents are substances that usually present an electric charge (negative and/or positive) that are put in contact with the wine, flocculating and precipitating the particles/compounds with an opposite electrical charge implicated in wine turbidity [18,19]. Bentonite fining is the most-used process to avoid protein instability in white wine, with the dose used being preferentially determined previously by stability tests [20]. However, bentonite fining can affect wine quality, for example, by removal of colour and aroma compounds $[7,21]$ and, therefore, can affect wine sensory characteristics [22]. Therefore, alternative techniques to bentonite fining for this goal have been studied, such as ultrafiltration $[6,23,24]$, addition of proteolytic enzymes $[25,26]$, flash pasteurisation [27,28], other adsorbents (silica gel, hydroxyapatite and alumina) [29], zirconium oxide [30-32], natural zeolites [33,34], chitin and chitosan [35,36], carrageenan [5,37] and the use of some mannoproteins $[19,38]$.

\section{Profiling and Characterisation of Wine Proteins}

Wine proteins are composed of grape proteins of Vitis vinifera and, in lower levels, by proteins from the autolysis of Saccharomyces cerevisiae [2,39]. Soluble proteins in grapes and wine have a molecular weight (MW) over a wide range, from 6 to $200 \mathrm{kDa}$ [40] and isoelectric point (pI) from 2.5 to 8.7 [41-43] (Table 1). The concentration of each fraction depends, among other factors, on grape variety [44-46], the state of maturity of the grape berry at harvest (the protein content increases as the berry matures) [47], region climate conditions, soil, vineyard management [48], and winemaking conditions [47], that intensely affect the final protein levels [30,49]. The methods used by the different authors for protein determination can also be determinants for the described range of wine protein content found in the literature. Their levels, in untreated wine, usually range from 15 to $300 \mathrm{mg} / \mathrm{L}$ [2,4,9,50,51]; however, contents as high as $700 \mathrm{mg} / \mathrm{L}$ have been described [52]. Moreover, the levels of specific proteins can vary widely. Mierczynska-Vasilev et al. [53] determined levels of 182 and $11 \mathrm{mg} / \mathrm{L}$ of thaumatin-like proteins and chitinases for Semillon and Sauvignon Blanc, respectively. The proteins implicated in wine protein instability resist the winemaking process, since they are highly resistant to proteolytic activities of grape and yeast proteases and are stable under high ethanol conditions and at the low $\mathrm{pH}$ values of must and wines [54].

For the characterisation of wine proteins, due to their very low concentration in wines and the presence of other compounds in the wine matrix, a mandatory first step is in most of the protocols concentration and purification by dialysis [55,56]. Ultrafiltration [26] and precipitation with an organic solvent, such as ethanol, methanol, or acetone [40], or ammonium sulphate precipitation [57,58] have also been used (Figure 1). After its separation from the wine, and before its characterisation, the protein content is quantified by traditional methods that used to fail in wines due to the existence of interfering compounds, such as polyphenols in Lowry's method or peptides in Biuret's method [59]. For this reason, the proteins are quantified after purification by chromatography using different approaches, such as (i) summing the total amino acid content [41] or (ii) using the area of the peak obtained by ultraviolet (UV) absorbance at $280 \mathrm{~nm}$ [60]. Another method commonly used to quantify proteins is Bradford's method, which has been widely used in the quantification of wine proteins [23,61,62]. Wine proteins can be further characterised by native-polyacrylamide gel electrophoresis (PAGE) [40,61-66] and PAGE with denaturating conditions (SDS-PAGE) [45,61,65-72]. The use of isoelectric focusing (IEF) in the analysis of proteins from grape must or wine $[1,41,61,65,71]$, based on agarose gels [41], or polyacrylamide either 
in a tube [23] or on a plate [55], or PAGE with denaturating conditions (SDS-PAGE) [73,74] or lithium dodecyl sulphate polyacrylamide gel electrophoresis (LDS-PAGE) $[23,75,76]$, or after fast protein liquid chromatography (FPLC) protein fractionation [72,77], has also been employed (Figure 1). More recently, the powerful two-dimensional gel electrophoresis (2D-GE) has been applied with great success [57], allowing the separation of more than 300 proteins or polypeptide fractions from a Chardonnay wine. In sparkling wine and in aged white wine, to a lesser extent, capillary electrophoresis (CE) has been used successfully $[56,78]$ and high-performance capillary electrophoresis (HPEC) was used to create a wine protein profile [79]. Moreover, chromatography has been extensively used to separate and characterise wine proteins, such as, for example, molecular exclusion [80], reverse phased [40], or affinity interactions [81]. Fast protein liquid chromatography (LC) with ion exchange has been also used for wine characterisation, either using cation exchange $[45,82,83]$ or anion exchange [45] (Figure 1). More recently, nano-high-performance liquid chromatography (nano-HPLC) [84] and nanoscale liquid chromatography coupled to tandem mass spectrometry (nano-LCMS/MS) [58] were used for protein separation and, in the case of the use of mass spectrometric techniques, also their identification. Mass spectrometry has become a central technique for protein identification, characterisation and quantification with its increasing sensitivity and applicability to complex samples. Mass spectrometric techniques are based on the separation of ionised molecules according to their mass-to-charge $(\mathrm{m} / \mathrm{z})$ ratios. Mass spectrometry (MS) can be used as an off-line technique but, nowadays, is more frequently coupled to liquid chromatography and capillary electrophoresis. Mass spectrometers can be used for the simple measure of the polypeptide molecular weight or for the determination of other important structural features like the amino acid sequence, by subjecting the selected ions to fragmentation through collision (tandem mass spectrometry (MS/MS)), allowing us to obtain detailed structural characteristics of the peptides from the analysis of the masses of the obtained fragment ions (Figure 1). A range of mass spectrometry-based analytical platforms and experimental strategies have emerged in the last years. Generally, all mass spectrometry-based proteomic workflows comprises three stages: (i) proteins are isolated from their source and can be further fractionated, the protein sample is digested, and the resulting peptides can also be further fractionated. (ii) The peptides after digestion are analysed qualitatively and quantitatively by mass-spectrometry. (iii) This approach generates a large amount of data that are analysed by appropriate software tools to deduce the amino acid sequence and, if applicable, the quantity of the proteins in a sample. The peptide identity is obtained through the tandem mass spectra by database searching [85], according to established guidelines to generate consistent results [86]. Additionally, a suitable statistical analysis of the search results is critical to ensure confidence in the identification [87].

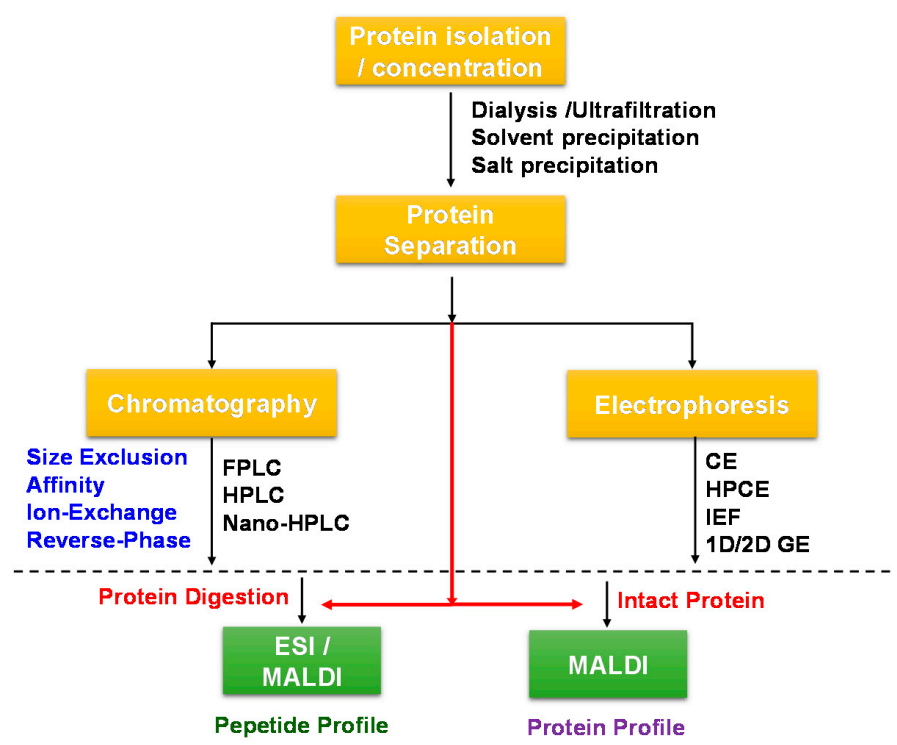

Figure 1. Typical workflow for wine protein characterisation. 
MS-based techniques have been applied to study the wine proteins and these applications have been reviewed by Flamini and Rosso [88] and Nunes-Miranda et al. [89], including the use of direct MS analysis after MALDI ionisation [90,91] or after previous protein cleavage with trypsin [92]. Direct infusion electrospray ionisation mass spectrometry (ESI-MS) has also been used to obtain the fingerprint of wines by Cooper and Marshall [93] and Catharino et al. [94].

Table 1. Isoelectric point $(\mathrm{pI})$ and molecular weight $(\mathrm{kDa})$ identified in different protein fraction from grape and wine.

\begin{tabular}{ccccc}
\hline \multicolumn{2}{c}{ Isoelectric Point $(\mathbf{p I})$} & \multicolumn{2}{c}{ Molecular Weight (MW) } & \multirow{2}{*}{ References } \\
\cline { 1 - 3 } Grape & Wine & Grape & Wine & \\
\cline { 1 - 3 } & $3.1-8.3$ & & & {$[61]$} \\
& $4.0-8.2$ & & $10.0-70.0$ & {$[72]$} \\
& & & $15.5-69.0$ & {$[45]$} \\
$5.6-7.6$ & $4.1-5.8$ & $11.2-190.0$ & & {$[75]$} \\
& & $19.0-100.0$ & & {$[73]$} \\
& $4.6-8.8$ & & $12.0-41.0$ & {$[74]$} \\
& & $18.0-23.0$ & {$[64]$} \\
& $3.1-9.2$ & & $11.0-88.1$ & {$[47]$} \\
& $3.0-5.6$ & & $14.0-94.0$ & {$[65]$} \\
& $3.2-9.0$ & & & {$[68]$} \\
$3.6-9.0$ & & $6.0-200.0$ & {$[40]$} \\
& & $10.0-50.0$ & {$[95]$} \\
& & $10.0-64.0$ & {$[70]$} \\
& & $21.0-65.0$ & {$[76]$} \\
& & & {$[41,42]$} \\
\hline
\end{tabular}

\section{Proteins Responsible for Wine Haze}

The first studies done concerning wine protein instability were performed by Koch and Sajak [96] who found that the heat-formed sediments contained two main electrophoretic fractions with different heat sensitivities. Moretti and Berg [64] and Bayly and Berg [66] fractionated and analysed wine proteins, concluding that, among grape and wine proteins, those protein fractions with low isoelectric points and low molecular weights were more sensitive to heat treatment and were responsible for wine protein instability. Furthermore, Hsu et al. [23], using ultrafiltration followed by two-dimensional electrophoresis to separate wine proteins, came to the same conclusion, showing that the principal proteins responsible for the white wine protein instability have a low molecular weight $(12.6-30 \mathrm{kDa})$ and $\mathrm{pI}$ (4.1-5.8) and also contain glycoproteins. In muscadine wines, Lamikanra and Inyang [74] proposed that proteins with a molecular weight higher than $32 \mathrm{kDa}$ were also unstable. This was later confirmed by Waters et al. [97], who separated and fractionated wine proteins using a combination of salting out with ammonium sulphate and ultrafiltration, showing that the protein fractions with those characteristics ( 24 and $32 \mathrm{kDa}$ ) were more sensitive to high temperatures and contribute to wine instability and haze formation. The same author also confirmed [6] that the lower molecular weight protein fractions may be more important to wine haze, showing that the protein with $24 \mathrm{kDa}$ caused nearly $50 \%$ more haze, at the same concentration than the protein fraction with $32 \mathrm{kDa}$.

Some authors stated that wine protein haze is associated to the total wine protein content, with wines containing higher total protein concentration, showing also more predisposition to becoming unstable $[2,51]$. However, other authors argue that wine protein instability is not associated to wine total protein content $[2,64,98]$ as each individual wine protein fraction behaves differently $[66,69,75,99]$.

Subsequent works indicated that proteins responsible for wine instability are pathogenesis-related proteins $[3,21,100]$. Pathogenesis-related proteins are essential for plant performance, such as disease resistance, development, and general adaptation to stressful environments [101]. Due to their high quality, Vitis vinifera is the most extensively cultivated species for winemaking; however, it is mainly vulnerable to pathogens, particularly fungi and oomycetes, such as Botrytis cinerea and Plasmopara 
viticola, respectively [54]. As a defence mechanism against several pathogens, pathogenesis-related proteins are synthesised in response to infection by pathogens, although they are constitutively expressed during berry ripening [4], for repairing the damage caused to the plant [102]. In Vitis vinifera grapes, the two major pathogenesis-related (PR) proteins isolated from wine, with a globular structure and a positive charge at the normal wine $\mathrm{pH}$, are thaumatin-like (PR-5 type, proteins fraction with $24 \mathrm{kDa}$ ) [21] and chitinases (PR-3 type, protein fraction with $28 \mathrm{kDa}$ ) [21,103]. Other minor PR proteins (e.g., osmotins, invertases, $\beta$-1,3-glucanases, lipid transfer proteins) are also present in wine $[90,104]$. Different isoforms of thaumatin-like proteins and chitinases have been identified in grape juices of different Vitis vinifera varieties, with a wide range of molecular weight 20-30 kDa, and an isoelectric point between three and five $[1,2,105,106]$. These proteins are also the main soluble proteins from Vitis vinifera $[50,100]$ and have been considered responsible for haze development in bottled white wine during storage and transportation [9,54,77,100,103,107-109]. They are synthesised during development regardless of variety [46], region and year [21,54,90,110] and increase during ripening; consequently, riper grapes are also more susceptive to protein haze [50]. These proteins (chitinases and thaumatin-like protein) have a high number of disulphide bonds that contribute to their highly stable structures and resistance throughout the winemaking process (that means, resistance to proteolysis and stable at wine acid $\mathrm{pH} 3.0-3.8)[2,21,111]$.

Chitinase proteins are low molecular weight proteins and are sensitive to temperature variations [100] and $\mathrm{pH}$ [112]. Thaumatin-like proteins are characterised mainly by their higher thermostability and by presenting no significant conformational variations or aggregation when exposed to $\mathrm{pH}$ variations [112]. This unequal behaviour appears to be associated to the differences in the secondary structure of both protein families, globular for thaumatin-like proteins and elliptical for chitinases [112,113]. Pocock et al. [50] additionally studied the variation in pathogenesis-related proteins concentrations among grape varieties for Muscat of Alexandria, Sultana, Sauvignon Blanc, Pinot noir and Shiraz grape juices with thaumatin-like proteins/chitinases of 119/118, 119/76, 35/21, 23/44 and 18/9 being observed, respectively. These authors have also observed that berry damage during mechanical harvesting, associated with a long transport time, will also induce the production of pathogenesis-related proteins as a result of a grape defence mechanism before pressing [114]. Thaumatin-like protein and chitinase differences in heat stability support the idea that protein composition may impact haze formation in wines $[13,115,116]$. In fact, the thaumatin-like protein ( $24 \mathrm{kDa}$ fraction) contributed to twice as much haze as the chitinase (32 kDa fraction) [6,12,97]. However, chitinases have been shown to have a major importance in wine haze as they are the most sensitive to precipitation, and a linear correlation was found between chitinase wine concentration and wine haze formed $[13,32,108]$. The evidence that chitinases are primary contributing proteins to wine haze formation is based on thermal unfolding studies. Falconer et al. [100] showed that chitinases have a low melting temperature, with denaturation in minutes at temperatures $>40{ }^{\circ} \mathrm{C}$, compared to weeks needed for the thaumatin-like protein under the same circumstances. Chitinases have a denaturation half-life of 6 min at $55^{\circ} \mathrm{C}$, thus extrapolating down to a denaturation half-life of 3 days at $35^{\circ} \mathrm{C}$ or 2 years at $25^{\circ} \mathrm{C}$ compared to the thaumatin-like protein, which had a melting temperature of $62{ }^{\circ} \mathrm{C}$, with a calculated denaturation half-life of 300 years at $25^{\circ} \mathrm{C}$. On the other hand, Sauvage et al. [1] (2010) showed that vacuolar invertase (GIN1), from the grapes and $\beta-(1-3)$-glucanases (32 kDa fraction), also considering pathogenesis-related proteins, can influence haze formation $[107,110]$. Besides the presence of Vitis vinifera thaumatin-like protein bands, $\beta$ - $(1,3)$-glucanase and ripening-related protein-like (27.4 kDa) Grip22 precursor have also been identified in the natural protein haze of white wines $[21,107,117]$. Additionally, no correlation between the total amount of protein existing in wine and protein instability has been observed [107]. These authors showed that the protein proportion of the natural precipitates was only $10.3 \%(w / w)$, using a direct protein analysis (Bradford dye-binding assay) while phenolic compounds and polysaccharides represented $7.2 \%$ and $4.4 \%$, respectively. 


\section{Factors That Affect Wine Protein Stabilisation}

Although the denaturation of some wine proteins results in aggregation and flocculation, rendering a turbid suspension and eventually the formation of precipitates [4], other non-proteinaceous wine compounds and factors can also be implicated in wine protein haze formation. It has been observed that wines with very similar protein fractions can have different haze potential [118]. However, wine ethanol concentration showed no significant effect on wine protein turbidity formation [119]. The most studied mechanism for wine protein instability and haze development is the protein-polyphenol interaction $[67,77,95]$. Wine proteins, to form turbidity, needed the presence of procyanidins, as wine proteins only (isolated and added back into a model wine) did not provoke turbidity [120,121]. A model for the interaction between haze-active polyphenol and haze-active protein was proposed by Siebert et al. [122] and showed that the quantity of haze developed depended on both protein and polyphenol content and on their ratio. In addition, wine $\mathrm{pH}$ has been implicated in protein haze formation, Yokotsuka and Singleton [123], showed that the turbidity of a protein-polyphenol complex is enhanced with a pH increase from 2.5 to 3.7 (model wine solution with $10 \%$ ethanol). Later Batista et al. [9] postulated that the protein haze formation is an isoelectric precipitation mechanism. Marangon et al. [108] verified that haze development in white wines is associated to hydrophobic interactions between proteins and tannins occurring on the hydrophobic tannin-binding sites of proteins that can be exposed depending on heating and reduction. Esteruelas et al. [99] found numerous phenolic compounds in protein haze, such as tyrosol, trans-p-coumaric, trans-caffeic, vanillic, protocatechuic, syringic, gallic, ferulic, shikimic acids, (+)-catechin and ethyl coumaric acid ester; quercetin and cyanidin were also detected after acid hydrolysis showing the existence of procyanidins. Phenolic compounds can also rise haze development by crosslinking denatured proteins to stimulate aggregate development [115], and the elimination of phenolic compounds from wines has been observed to reduce haze development [12].

Media conditions such as $\mathrm{pH}$, ionic strength, metal ions [124], polysaccharides [125], organic acid concentration $[9,11,12]$, polyphenols/phenolic compounds $[4,10,12,126]$ and sulphate anions, formerly designated as the $X$ factors essential for protein turbidity $[12,13,127]$, affect protein haze formation. Wine $\mathrm{pH}$ is a serious inducing factor in protein haze formation, with model wines at $\mathrm{pH} 4.0$ inducing higher protein aggregation and haze after heating than model wines of $\mathrm{pH} 3.0[9,11,51]$. Increasing electrical conductivity and ionic strength, such as by the addition of sulphate anions or sodium cations, also rise haze development after heating, by decreasing the electrostatic repulsion of proteins [11-13]. Other ions, comprising chloride, tartrate, $\mathrm{Fe}^{2+} \beta+$ and $\mathrm{Cu}^{+}{ }^{2+}$, do not affect haze development in model wines [12]. Increasing protein concentrations ( 9 and $25 \mathrm{mg} / \mathrm{L}$ ) and electrical conductivity $(0.134$ and $0.163 \mathrm{~S} / \mathrm{m}$ ) result in more visible haze formation, while low iron concentrations $(0.3$ and $0.9 \mathrm{mg} / \mathrm{L})$ seem to improve the protein stability of white wines, so haze was observed to be negatively correlated with iron levels [128]. In contrast, McRae [129], in a study using several white wines, showed a negative correlation between electrical conductivity and white wine haze formation, probably related to the lower sulphate concentration of these wines $(150-550 \mathrm{mg} / \mathrm{L})$ compared to the sulphate concentration of the model wines (500-4000 mg/L) used by Marangon et al. [13]. Polysaccharides may potentially decrease protein aggregation in wines by forming a protective layer around unfolded proteins [17], while the role of polysaccharides in haze development in reconstituted wines is variable $[116,130,131]$.

Organic acids are recognised to interact with phenolic acids, free amino acids, pectic compounds, tannins and sulphate ions preventing, in this way, their interaction with proteins [10]. These authors showed that organic acids presented a stabilising effect on the wine potential to the formation of protein haze. This effect has been attributed to electrostatic interactions that depend upon the organic acid $\mathrm{pKa}$ and protein $\mathrm{pI}$ values and on the medium $\mathrm{pH}$.

Pocock et al. [12] suggested that sulphate ions could be the non-proteinaceous factor for protein haze formation, as they promote protein-protein hydrophobic interactions, as well as the suppression of electrostatic repulsion between proteins by the increase in the ionic strength of the medium [13]. In a study dedicated to the characterisation of some wine haze-forming 
thaumatin-like proteins, it was shown that potassium hydrogen sulphate can modulate the haze formation [106]. Van Sluyter et al. [115] reviewed the mechanism of protein haze formation and proposed a three-stage process that included protein unfolding, protein self-aggregation, and aggregate cross-linking, highlighting the role of sulphate ions in all steps. More recently, Chagas et al. [127] showed the importance of sulphur dioxide present in wines in the irreversible denaturation and aggregation phenomena of thaumatin-like proteins and their contribution to wine protein haze formation. The presence of $\mathrm{HSO}^{-}$induces the cleavage of the thaumatin-like proteins' intra-disulphide bonds, enhanced by the high temperature-induced unfold of these proteins. The exposed hydrophobic surfaces and buried cysteine/cystine residues contribute to the inter-protein interactions. The formation of proteins S-thiosulfonates by the reaction of $\mathrm{HSO}_{3}{ }^{-}$and disulphide bonds promotes the formation of inter-disulphide bonds between thaumatin-like proteins that are responsible for wine protein aggregation following a nucleation-growth kinetic model.

\section{Protein Stability Tests for Wine Quality Control-Advantages and Disadvantages}

To decrease the risk of turbidity and/or formation of organic deposits in white wine related to the thermolabile wine protein or colloidal suspensions precipitating over wine before bottling, diverse protein stability tests have been developed and are used today in the wine industry $[69,77,119,132]$. These tests are also performed to define the dose of fining agent necessary in the fining treatments for stabilising wine concerning the protein haze formation $[133,134]$. In general, protein stability tests include the determination of wine total protein content or methods involving a reduction in wine protein solubility by applying heat [135-137] or chemicals. As protein chemical precipitants, trichloroacetic acid [8,136], phosphomolybdic acid, also called bentotest [138], and the increase in the ethanol [8] or tannin content [139], have been described. In agreement with Esteruelas et al. [69], these tests originate dissimilar precipitates, as well as differences from the natural precipitate formed in protein-unstable wines and, therefore, they do not perfectly reproduce the natural phenomenon. Forced precipitation leads to the formation of precipitates with increased protein content, polysaccharides and polyphenols in relation to the precipitates obtained naturally; they contain proteins that otherwise would not appear in the natural precipitate [69]. The heat test using lower temperatures $\left(60^{\circ} \mathrm{C} / 4\right.$ days followed by $6 \mathrm{~h}$ at $4{ }^{\circ} \mathrm{C}$ ) does not precipitate thaumatin-like proteins and the ethanol test precipitates a great number of polysaccharides, making neither test suitable. Esteruelas et al. [69] showed that the higher temperature $\left(90^{\circ} \mathrm{C} / 1 \mathrm{~h}\right.$ followed by $6 \mathrm{~h}$ at $4{ }^{\circ} \mathrm{C}$ ) heat test is more like the natural precipitate concerning its chemical composition and, therefore, appears to be the most suitable stability test. Additionally, different tests yield different instability indexes and, therefore, different doses of fining agents are needed in order to achieve stability according to their results. Protein stability tests do not correlate well with wine total protein concentration since individual protein fractions act differently [69] and, therefore, total protein assays are limited concerning the prediction of wine protein stability and do not take into account the role that other wine components play in protein instability [12].

\subsection{Heat Test}

The heat test is the most-used method in the industry for predicting wine haze-forming potential and determining the relative protein instability, being probably the most reliable method to predict the haze/sediment formation in the bottle during storage. There is no standard protocol to perform the heat test, as numerous researchers and the wine industries use different heating times and temperatures (Table 2) $[9,140]$. This test is supported by wine sample heating at a high temperature over a period of time and, therefore, relies on protein heat denaturation to induce precipitation. This test is applied to simulate the formation of protein turbidity and is considered suitable to establish the adequate doses of fining agent necessary to eliminate heat-unstable proteins, being less affected by other wine compounds and conditions, such as metal cations and $\mathrm{pH}$ [119]. Wine proteins present different heat sensibilities to form precipitates $[23,75,76]$ and, therefore, the most-used test is that described by Pocock and Rankine [137], where wine is heated at $80^{\circ} \mathrm{C}$ for $6 \mathrm{~h}$. Ribéreau-Gayon et al. [135] suggested that 
wine must be heated at $80{ }^{\circ} \mathrm{C}$ for $10 \mathrm{~min}$. Instead, Esteruelas et al. [69] indicated that heating wine at $90{ }^{\circ} \mathrm{C}$ for $1 \mathrm{~h}$, when compared to the other tests, forms a precipitate with a composition similar to the natural precipitate.

One of the described drawbacks of these tests is the increase in phenolic compound oxidation and condensation with proteins at high temperatures [119], which can cause protein precipitation and, therefore, interfere with the test results. However, Sauvage et al. [1] determined that the heat test can induce the precipitation of almost all wine proteins, leading to an overestimation of the fining agent doses required for stabilisation.

Protein aggregation mechanisms changes between long-term storage at lower temperatures and heating and can be influenced by the protein's isoelectric point and the $\mathrm{pH}$ of the solution [11]. At a lower temperature $\left(25^{\circ} \mathrm{C}\right)$, protein aggregation is improved by a low $\mathrm{pH}(\mathrm{pH} 2.5)$.

Over time, there is a variation in protein conformation, possibly exposing hydrophobic groups, which triggers aggregation. Proteins are completely unfolded [100] (at higher temperatures $\left(70{ }^{\circ} \mathrm{C}\right)$ and are more disposed to aggregation at a higher $\mathrm{pH}(\mathrm{pH} 4.0)$ [11]. In model wines, haze formation and protein aggregation can rise upon cooling with more haze development after extensive cooling times [11]. Cooling time may, consequently, be essential for the heat test results. Variations in heat test conditions are, therefore, likely to compromise the accuracy and repeatability of the results.

McRae et al. [129] showed that in white wines heated at $80^{\circ} \mathrm{C}$ for 0.5 to $6.0 \mathrm{~h}$ and then cooled for $0.5-18 \mathrm{~h}$ at either 0,4 or $20^{\circ} \mathrm{C}$, prolonged heating times, prolonged cooling times and a lower cooling temperature all increased the quantity of haze formed in the heat test. For example, heating for $6 \mathrm{~h}$ and cooling for $18 \mathrm{~h}$ at $4{ }^{\circ} \mathrm{C}$ ( $24 \mathrm{~h}$ test) commonly yielded an increased predicted bentonite dose by up to $0.3 \mathrm{~g} / \mathrm{L}$ compared to heating for $2 \mathrm{~h}$. These authors concluded that wines heated for $2 \mathrm{~h}$ at $80{ }^{\circ} \mathrm{C}$ and then cooled for $3 \mathrm{~h}$ at $20^{\circ} \mathrm{C}$ ( $5 \mathrm{~h}$ heat test) resulted in a repeatable production of haze and needed a bentonite fining dose for wine stabilisation. The wine protein haze formation in these tests is explained by the thermal treatments that expose more protein-active sites for haze-active polyphenol binding [122] and the cooling process could decrease the solubility of protein-polyphenol complexes [123].

Although this is one of the most used tests, the greatest disadvantage is the time needed for its execution.

Table 2. Heat test conditions recommended for heating and cooling.

\begin{tabular}{ccc}
\hline Heating & Cooling & Reference \\
\hline $60{ }^{\circ} \mathrm{C}$ for 4 days & $4{ }^{\circ} \mathrm{C}$ for $6 \mathrm{~h}$ & {$[29]$} \\
$80^{\circ} \mathrm{C}$ for $2 \mathrm{~h}$ & $4^{\circ} \mathrm{C}$ for $16 \mathrm{~h}$ & {$[134]$} \\
$80^{\circ} \mathrm{C}$ for $2 \mathrm{~h}$ & $0^{\circ} \mathrm{C}$ for $2 \mathrm{~h}$ & {$[5,127,141]$} \\
$80^{\circ} \mathrm{C}$ for $2 \mathrm{~h}$ & $4{ }^{\circ} \mathrm{C}$ for $2 \mathrm{~h}$ & {$[128]$} \\
$80^{\circ} \mathrm{C}$ for $2 \mathrm{~h}$ & $20^{\circ} \mathrm{C}$ for $3 \mathrm{~h}$ & {$[37]$} \\
$80^{\circ} \mathrm{C}$ for $3 \mathrm{~h}$ & $20^{\circ} \mathrm{C}$ for $30 \mathrm{~min}$ & {$[131,142]$} \\
$80^{\circ} \mathrm{C}$ for $6 \mathrm{~h}$ & $4^{\circ} \mathrm{C}$ for $16 \mathrm{~h}$ & {$[9,137,143,144]$} \\
$80^{\circ} \mathrm{C}$ for $30 \mathrm{~min}$ & No specified cooling time & {$[145,146]$} \\
$90^{\circ} \mathrm{C}$ for $1 \mathrm{~h}$ & $4^{\circ} \mathrm{C}$ for $18 \mathrm{~h}$ & {$[147]$} \\
$90^{\circ} \mathrm{C}$ for $1 \mathrm{~h}$ & $4{ }^{\circ} \mathrm{C}$ for $6 \mathrm{~h}$ & {$[29]$} \\
\hline
\end{tabular}

\subsection{Trichloroacetic Acid Test}

The trichloroacetic acid (TCA) test is established on the ability of this acid to precipitate all proteins present in wine, yielding results close to those obtained by the determination of the wine total protein content [8].

The TCA test consists of the addition of $1 \mathrm{~mL}$ of a TCA solution at $55 \%(v / v)$ to $10 \mathrm{~mL}$ of wine followed by heating in a water bath at $100{ }^{\circ} \mathrm{C}$ for $5 \mathrm{~min}$, and cooling and standing at room temperature for 15 min before measuring haze formation [23,76,77]. In agreement with Berg and Akiyoshi [136], 
this test can be correlated with protein stability; however, at the industrial scale it does not yield satisfactory results, because it overestimates the fining agent dose needed to stabilise the wine.

\subsection{Tannin Test}

The tannin precipitation test is based on the hypothesis that wine proteins could precipitate during wine storage by binding with phenolic compounds and, therefore, yield information about the amount of wine proteins able to be precipitated by tannins [119]. A previous work performed by Yokotsuka et al. [148] showed that the ability of phenolic compounds to bind to proteins increased with their degree of polymerisation. This test is influenced by numerous intrinsic wine factors, namely $\mathrm{pH}$, total protein content, iron content, copper and potassium, and, therefore, is not a good predictor of the fining agent dose needed to stabilise wines $[69,119]$.

\subsection{Bentotest}

The bentotest uses a solution of phosphomolybdic acid in $\mathrm{HCl}$ which precipitates wine protein by neutralising the protein charge, leading to aggregation with the molybdenum ion [23,76,77]. This procedure can precipitate all the proteins in the wine sample, being principally used to determine the bentonite dose. However, this test has the disadvantage of overestimating the fining agent used to stabilise the wine $[23,76,77]$.

\subsection{Ethanol Test}

The ethanol test is established on the reduction in the medium dielectric constant, resulting in a reduction in protein solubility [149], leading to the precipitation of the least soluble protein fractions at wine $\mathrm{pH}$. This test is significantly influenced by the total protein concentration, $\mathrm{pH}$, pectin, tartaric acid and calcium content, which may result in differences in the formation of wine turbidity [29]. Esteruelas et al. [69] also showed that polysaccharides are the key compounds precipitated by the ethanol addition to wines, followed by proteins and polyphenols. Therefore, the fining agent needed for wine protein stabilisation, based on the ethanol test, would be done in excess.

\subsection{Spectroscopic Methods}

The conventional stability tests previously described are time consuming. Therefore, the use of near-infrared spectroscopy (NIR) to predict wine protein instability seems to be promising. Moreover, the feasibility of using infrared spectroscopy for the estimation of protein instability haze development in white wines resulting from heat and colloidal stability tests has been explored for the first time by Versari et al. [150]. The authors analysed one hundred and eleven white wines using the near and mid-infrared spectral region and, simultaneously, the heat and colloidal (ethanol addition) stability tests were done on the same wines. Partial-least squares (PLS) regression analysis was used to construct predictive models of the turbidity-acquired spectra. These authors proved that the turbidity obtained from the ethanol addition to the wine could be expected from the short wavelength NIR spectra.

\section{Wine Protein Stabilisation-Strategies and Treatments}

Wine protein stabilisation consists of the removal of unstable proteins. This stabilisation process is usually achieved by bentonite fining [4]. However, bentonite fining treatment presents some disadvantages, resulting in a loss of economic value [7]. Decreasing bentonite applications and/or finding alternative technologies or products, such as the use of yeast mannoproteins $[19,38,140]$, the use of regenerable adsorbents [29-34], carrageenan, chitin, chitosan, ultrafiltration and flash pasteurisation or the use of proteolytic enzymes [5,6,23-28,35-37], are of utmost interest for the wine industry. 


\subsection{Winemaking Practices to Prevent or Reduce Wine Protein Instability}

The climate conditions and grape variety can significantly influence the wine protein composition and wine protein stability. Intense grape maturation in white grape varieties must be avoided due to the higher concentration of proteins and phenolic compounds in the grape juice [135]. The application of pectolytic enzymes contaminated with proteolytic activity can decrease the level of proteins in the grape juice. In protein-rich grape varieties, the pre-fermentation maceration operation with enzyme extraction must be avoided due to the high levels of proteins and phenolic compounds that can be extracted, increasing the wine protein instability. In the Bordeaux region, in grape varieties like Sauvignon Blanc and Semillon, the skin contact can increase by up to more than $50 \%$ of the levels of unstable proteins. The oxidative protection of the grapes with $\mathrm{SO}_{2}$ can increase the level of proteins; in protein rich grape varieties, the $\mathrm{SO}_{2}$ levels must be minimised and the oxidative protection should be performed using inert gases like $\mathrm{CO}_{2}$ [135].

Tannins from the grape stalks have a special tendency for interacting with grape juice proteins when the grapes are pressed [151]. Thus, mechanical grape-harvesters that eliminate stalks may be considered one contributing factor in the protein instability of wines made from certain grape varieties [152].

In white grape varieties, like Moscatel, that consistently contain high levels of unstable proteins, the use of bentonite in juice clarification or during the grape juice fermentation can be useful to decrease the level of proteins [51].

\subsection{Bentonite Fining}

Bentonite has been used to improve wine limpidity and stability for many years and is still, today, the most used method for wine protein stabilisation, being one of the most efficient treatments widely used at the industrial scale to prevent haze formation after bottling and storage $[2,4,115]$.

Bentonites are complex hydrated aluminium silicates, mostly composed of at least $75 \%$ of montmorillonite. Montmorillonite has a multilayer structure of aluminium hydrosilicates, forming platelets [153] with exchangeable cations [154]. The exchangeable cations can be $\mathrm{Na}^{+}, \mathrm{Ca}^{2+}$, and $\mathrm{Mg}^{2+}$, and determine the bentonite type [22], namely sodium, calcium and magnesium bentonites, respectively [154] (Figure 2). Other cations are present, such as $\mathrm{K}^{+}$and $\mathrm{Fe}^{2+}$, but in minor amounts [155]. The different cations are complexed in the interlayer region and can influence the interlayer distance throughout the swelling and the adsorbing performance [156].

The predominant forms are calcium and sodium bentonites, but sodium bentonite is still the most extensively applied, as they swell more than calcium bentonites [154] and swelling can potentially increase the surface area-accessible adsorption for wine protein $[29,39,132,157]$. The processing time of sodium bentonite is less than calcium bentonite, but the quantity of sediment is greater for sodium bentonite, with calcium bentonite yielding more compact sediment. To enhance the adsorption properties of calcium bentonites, they are activated with sodium carbonate $\left(\mathrm{Na}_{2} \mathrm{CO}_{3}\right)$ at $80{ }^{\circ} \mathrm{C}$ [157], resulting in calcium-activated bentonites with similar or even better adsorption properties than sodium bentonites [154].

The bentonite wine fining involves the dispersion of the adsorbent and the adsorption of the solutes and sedimentation of the complex formed between the adsorbent and adsorbate [157]. Bentonite removes proteins by electrostatic interaction, forming complexes which can be removed by filtration. Proteins with a $\mathrm{pI}$ above the wine $\mathrm{pH}$ have an overall positive charge and can be adsorbed by bentonite via an exchange of sodium, calcium and magnesium ions [132]. Bentonite treatment efficiency depends, therefore, on bentonite type and dose, temperature, $\mathrm{pH}$ and wine composition [135].

The method used to prepare bentonite affects significantly its capacity to eliminate wine proteins [39]. Hydrated bentonite (with wine or water), can swell, increasing their surface area and forming a gel with a strong negative charge at the wine $\mathrm{pH}$. These negatively charged bentonites interact electrostatically with positively charged wine colloids, proteins, leading to flocculation $[1,22]$. However, high doses of bentonite produce lees that can contain $5 \%$ to $20 \%$ of the wine volume, 
resulting in wine losses $[4,113,158]$; the used bentonite cannot be recycled, having, therefore, a high environmental impact [31].
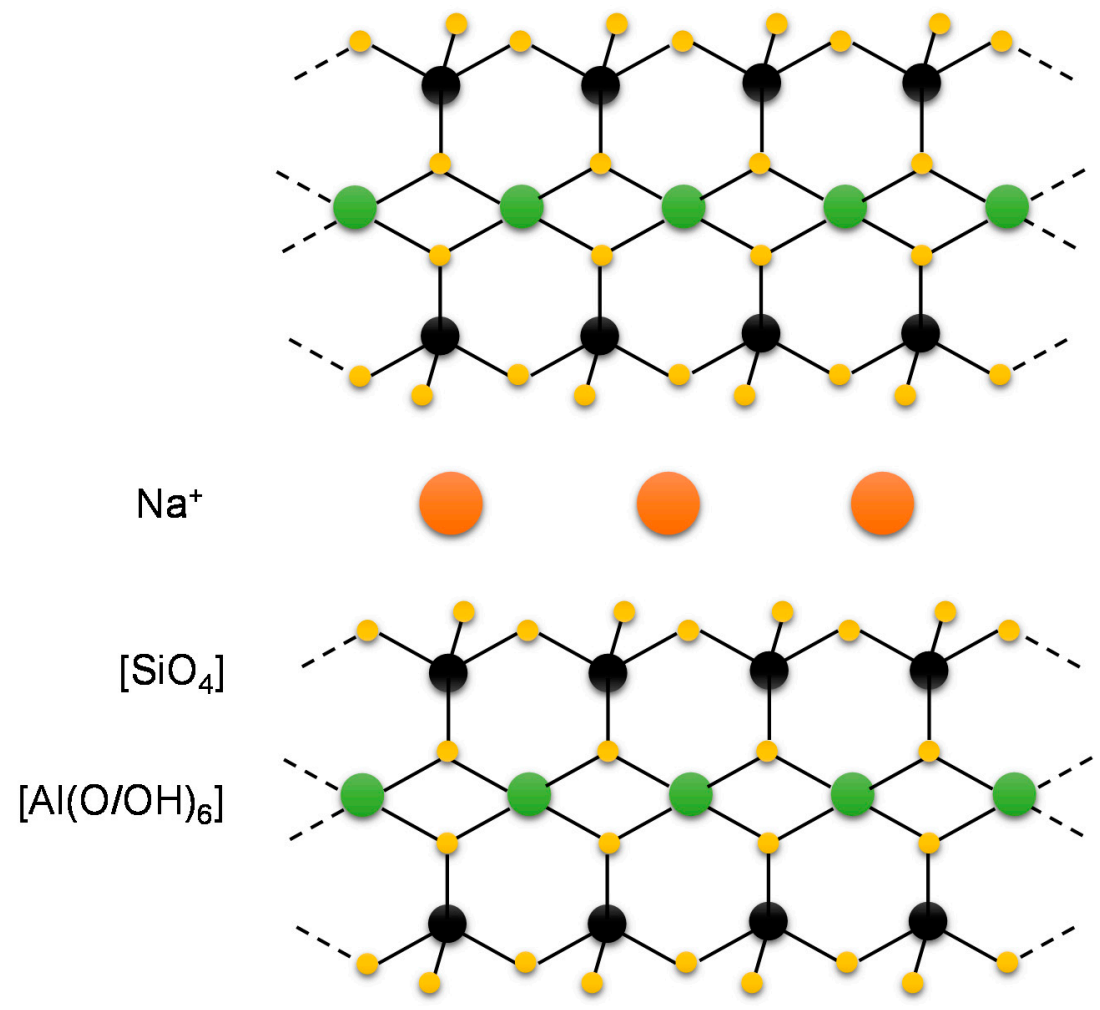

Figure 2. Schematic representation of the three-layer platelet formed by two layers of silicon oxygen tetrahedra and aluminium hydroxide sheet in sodium bentonite montmorillonite layer and sodium exchangeable cations, between adjacent platelets.

The competition with the cations $\left(\mathrm{Ca}^{2+}, \mathrm{K}^{+}, \mathrm{Na}^{+}\right.$, and $\left.\mathrm{Mg}^{2+}\right), \mathrm{pH}$ and ethanol concentration of the matrix can influence the protein adsorption [157]. According to Hsu et al. [23], pre-hydrated bentonite at a high temperature, low $\mathrm{pH}$, high alcohol concentration and low tannin, improved the clarification results. Lambri et al. [22] showed that the efficiency of bentonite adsorption changed with the different $\mathrm{pH}$ values, with more protein being removed at 3.60 than at $\mathrm{pH} 3.30$, this probably being related to the competition of hydrogen ions for adsorption.

Bayly and Berg [66] conclude that the elimination of the different wine protein fractions by bentonite addition did not happen in equal proportion. Bentonite first eliminates proteins with high pI (5.8-8.0) and intermediate MW (32-45 kDa). However, by 2D-GE, Hsu et al. [23], observed that, to stabilise wine, it is essential to eliminate proteins with lower pI (4.1-5.8) and lower MW (12.6 and $20-30 \mathrm{kDa}$ ), including glycoproteins, which represent a major fraction of proteins. This hypothesis is sustained by Lambri et al. [118] who, using five different types of activated sodium bentonite (with different labels), could selectively remove specific proteins implicated in the turbidity after heating. More recently, Jaeckels et al. [159] analysed the influence of a NaCa-combined bentonite on the protein concentration and composition of different wines showing a partial selectivity on protein adsorption. Notably, glycosylated proteins were not eliminated in considerable levels by bentonite. Using mass spectrometry, these authors showed that $96 \%$ of class IV chitinase was adsorbed by NaCa-combined bentonite, although changing adsorption behaviours were observed for different thaumatin-like protein isoforms, ranging from no removal to $98 \%$ elimination. The surface hydrophobicity of the proteins can explain these behaviour differences.

Dawes et al. [77] found that bentonite was not selective based on protein pI; therefore, bentonite fining could eliminate all protein fractions. Ferreira et al. [2] and Lambri et al. [22] stated that bentonite 
is not specific for proteins and may also eliminate other charged species or aggregates. However, the existence of certain wine colloids is positive, as they confer structure and volume to the wine, and contribute to the retention of aromatic compounds [160]; therefore, bentonite can also interact with wine aroma compounds [161], resulting in a loss of wine aroma and flavour [20,22,162,163]. Moreover, most odour-active molecules are indirectly eliminated via deproteinisation, and only a few odour-active molecules are directly eliminated through adsorption [22]. The impact of bentonite on wine aroma depends more on the aroma chemical nature (hydrophilic or hydrophobic characteristics) than on the direct bentonite impact. In wine with more hydrophilic aroma compounds, with a good protein affinity, a more negative impact on wine aroma by the bentonite treatment is observed [22]. Therefore, an excessive quantity of bentonite may have a negative effect on wine sensory characteristics.

On the other hand, it has been described that fining grape juice with bentonite can decrease the total dose of bentonite needed for wine stabilisation compared to wine fining [20]; however, contradictory results have been obtained [164,165]. Must fining negatively affects the amount of available nitrogen, the varietal and fermentation aromas, and wine quality $[20,22,162,166]$. Another approach is the application of bentonite during wine fermentation, first described by Ewart et al. [167], and more recently by other authors [164,168], showing the potential to decrease the bentonite dose required for wine stabilisation and, therefore, improve wine quality.

Besides the described negative effects when using bentonite for wine fining, it also shows a cation exchange effect and can increase wine cation levels, especially sodium ions, above the maximum limits [169].

Due to the negative impact on wine quality and wine volume losses from wine protein stabilisation by bentonite, alternative solutions to wine protein stabilisation have been studied and explored and are still under research today.

\subsection{Other Adsorbents}

The application of other adsorbents beside bentonite has been studied to access their efficiency, concerning protein instability, in stabilising wine. Zirconium dioxide, a metal oxide usually known as zirconia, is a material characterised by low thermal conductivity, low corrosion potential, hardness and high thermal and mechanical resistance [170]. Zirconium oxide has demonstrated the ability to adsorb wine-unstable proteins [30], stabilising the wine and eliminating, preferentially, the wine protein fractions between 20-30 kDa. This adsorbent allowed the stabilisation of the wine via a continuous stabilisation process with minor negative impacts [31,171] on the wine's physicochemical and sensory characteristics [30,31]. Marangon et al. [32] showed that, although white wines are stabilised by eliminating unstable proteins through adsorption using zirconium oxide pellets enclosed into metallic cage submerged in wine at $25 \mathrm{~g} / \mathrm{L}$ for $72 \mathrm{~h}$, the authors observed a slight decrease in fruit aroma and flavour intensity. This work also showed that the regeneration of this material can be relatively simple.

Mercurio et al. [33] and Mierczynska-Vasilev et al. [34] also proposed natural zeolites as alternative adsorbents for wine protein stabilisation. Natural zeolites have a highly negatively charged external surface allowing their interactions with other cations, or polar molecules High zeolite/wine ratios allowed wine protein stabilisation, and treatment with zeolite-rich powder significantly reduced potassium ion concentration, improving the tartaric stability [33,34]. It was determined that zeolite particle size in the range $20-50 \mu \mathrm{m}$ and treatment for $3 \mathrm{~h}$ were enough to reach complete heat stability using 4 or $6 \mathrm{~g} / \mathrm{L}$ for Semillion and Sauvignon Blanc or Chardonnay wine, respectively. Furthermore, it did not significantly affect the content of the most representative phenolic compounds related to taste, and not significantly affect the wine aroma quality after treatment [172]. Additionally, in contrast to bentonite, zeolites did not cause significant wine volume losses and can be reused as soil improvers in agriculture [34].

The adsorption of wine proteins by phenolic compounds (tannic acid derivatives), immobilised on agarose chromatography resins, has also been applied to stabilise wine concerning wine-unstable 
proteins [173]. Tannic acid derivatives revealed the capacity to eliminate wine proteins but suffered from a reduction in protein binding ability after a small number of regeneration cycles [173].

Sarmento et al. [29] studied the ability of diverse materials, such as swelling clays, low-swelling clay, ion-exchange resins, alumina, hydroxyapatite and silica gel as alternative adsorbents to eliminate wine proteins. The results show that packed columns with ion-exchange resins have good potential to adsorb proteins, but the colour and aroma of the wines were negatively affected.

\subsection{Mannoproteins}

In agreement with Gonçalves et al. [174], 32.2\% of the total polysaccharides existing in white wine are mannoproteins. They originate from the outer layer of the yeast cell wall, specifically from Saccharomyces cerevisiae, since they make up $35-40 \%$ of the cell wall. These polysaccharides are glycoproteins, highly glycosylated and are covalently linked to an amorphous matrix of $\beta-1,3$-glucan [175] and containing $10-20 \%$ of protein and $80 \%$ of D-mannose, with lower amounts of D-glucose and $N$-acetyglucosamine $[176,177]$. Mannoproteins contain $N$ - and $O$-linked carbohydrates bound to asparagine or serine or threonine residues, respectively. The $O$-glycosylated carbohydrates in mannoproteins are composed of short mannose chains linked to the hydroxyl groups of serine or threonine residue side chains through $\alpha$-glycosidic linkages. These short chains are normally formed by mannose residues, in which the inner first two are 1,2- $\alpha$-linked, while the outer mannose residues contain 1,3- $\alpha$-D linkages [178] (Figure 3). The $N$-linked glycans can be extended with an outer chain of 50 or more $\alpha 1,6$-linked Man residues that are widely substituted with short $\alpha 1,2$-Man side branches terminated in $\alpha 1,3$-linked mannose residues. Phosphodiester-linked mannose residues can also be attached to the $\alpha 1,2$-linked residues (Figure 3). Mannoproteins present in wine are heterogeneous with a molecular weight between 5-400 kDa; however, Waters et al. [179] identified a mannoprotein with $420 \mathrm{kDa}$ which was composed of $30 \%$ polypeptide and $70 \%$ carbohydrate, of which $98 \%$ was mannan. However, it is usually considered that the amount of mannoproteins released under winemaking conditions is too low to be effective in protein stabilisation [130].

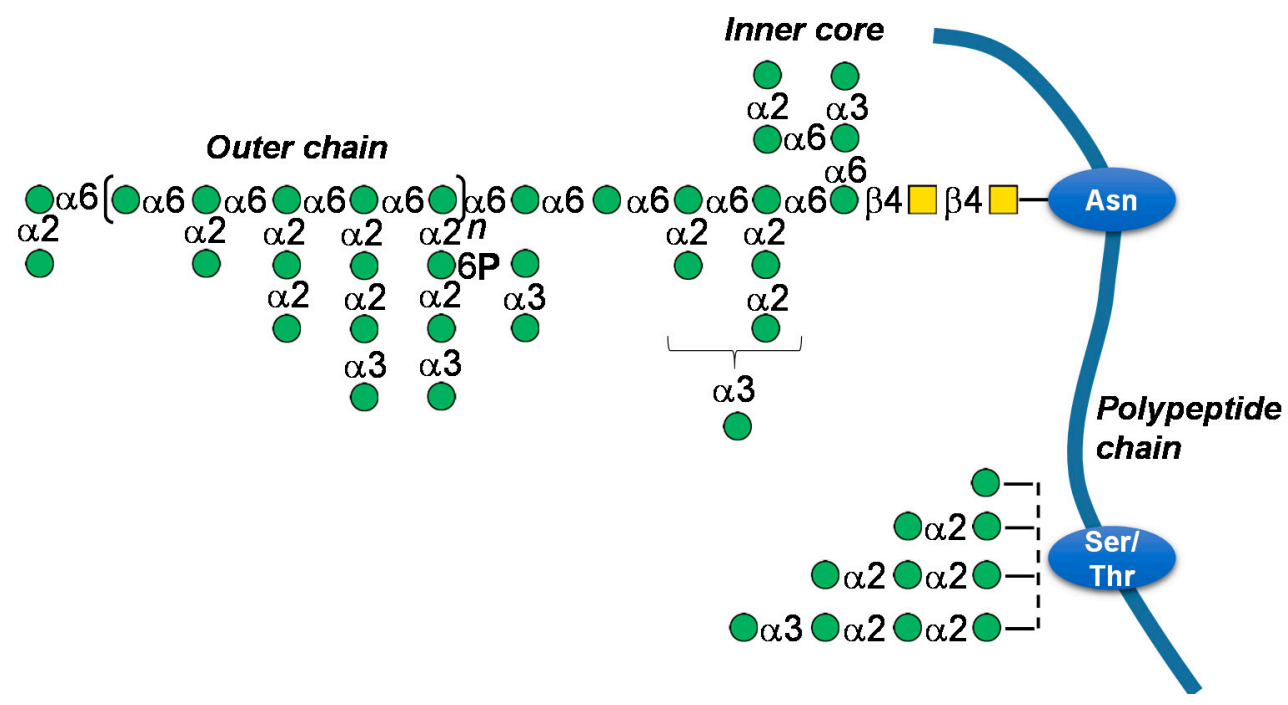

Figure 3. Some structural details of Saccharomyces cerevisiae mannan, adapted from Hernández et al. [180]. Structure was draw using the Symbol Nomenclature for Graphical Representation of Glycans, [181].

The application of mannoproteins in oenology has been suggested to decrease or even eliminate the use of bentonite and other treatments used for wine protein stabilisation. The treatment of wines with yeast mannoproteins was authorised by the International Organisation of Vine and Wine (OIV) in 2005, resolution: Oeno 4/01; 15/05 [182].

Mannoproteins for oenological application are extracted from the purified yeast cell wall, by enzymatic extraction, using exo- $\beta$ ( $1 \rightarrow 3$ )-glucosidase (EC 3.2.1.58) for glucan hydrolysis, or by 
physicochemical processes, such as the heat treatment of the yeast wall using a citrate buffer at $\mathrm{pH}$ $7[78,183,184]$. Biotechnological tools, such as engineered yeast strains (S. cerevisiae), for increasing mannoproteins levels have been applied to increase commercial mannoprotein production [140].

Mannoproteins are often selected considering their useful behaviour in protein stabilisation and haze decrease in white wines; furthermore, they could also exert a positive effect on wine quality $[4,17,19,38,179,185-190]$.

Waters et al. [17] have shown that wine mannoproteins protect unstable proteins, preventing wine turbidity when wine is exposed to high temperatures; these authors showed that this action does not prevent the precipitation of the proteins. Instead, they observed a decrease in particle size, justifying, in this way, the wine stabilisation observed when measured by turbidimetry.

Other glycoproteins have shown a protective effect, avoiding haze formation and conferring wine protein stability, including a fragment of yeast invertase (32 kDa) [130,191], wine arabinogalactan proteins with $210 \mathrm{kDa}$ [186], arabic gum and arabinogalactan proteins from apples [125].

\subsection{Polysaccharides from Seaweeds}

Agar, carrageenan and alginic acid, polysaccharides extracted from seaweeds, due to their negative charge at low $\mathrm{pH}$, can electrostatically flocculate and precipitate positively charged proteins and be a potential alternative for wine protein stabilisation $[5,37,192,193]$.

Carrageenans are a family of water-soluble, linear, sulphated galactans that are extracted from red seaweeds, called carrageenophytes, where they are the most abundant cell wall constituents. Carrageenans are composed of $\alpha-(1 \rightarrow 3)$-D-galactose units and $\beta$-(1 $1 \rightarrow 4)-3,6$-anhydro-D-galactose units (Figure 4). The galactose and 3,6-anhydro-D-galactose units of carrageenan can be sulphated with $15-40 \%$ of ester sulphate content and an average relative molecular mass well above $100 \mathrm{kDa}$. Several isomers of carrageenan are identified ( $\mathrm{K}_{-}, \mathrm{l}-$, and $\lambda$-carrageenans) and they differ in the number and position of the ester sulphate groups on the repeating galactose units (Figure 4) [194]. The primary differences that effect the properties of kappa, iota, and lambda carrageenan are the number and position of the ester sulphate groups on the repeating galactose units. The structure of $k$-carrageenan is composed of alternating 3-linked-D-galactose residues and 4-linked 3,6 anhydro-galactose residues, with an ester sulphate content of about $25-30 \%$ and 4-linked 3,6-anhydro-galactose content of about $28-35 \%$. Iota carrageenan has an additional sulphate group on C-2 of the 3,6-4-linked anhydro-galactose residue, resulting in two sulphates per disaccharide repeating unit. It has an ester sulphate content of $28-30 \%$ and about a $25-30 \% 3,6$-anhydro-galactose content. Lambda carrageenan contains three sulphate groups per disaccharide unit, with the third sulphate group being linked at the C-6 position of the 4-linked residue, with an ester sulphate content of about 32-39\% and no 3,6-anhydro-galactose content [195].

Agar is, like carrageenan, composed of heterogeneous populations of molecules differing in their physicochemical properties, composed mostly of two types of polysaccharides, including agarose, composed of a linear chain of 3-O-substituted $\beta$-D-galactopyranosyl residues joined by $(1 \rightarrow 4)$ linkages to 3,6-anhydro- $\alpha$-L-galactopyranosyl residues (structure 1 in Figure 5, agarobiose). Agaropectin, the other agar polysaccharide, is a branched polysaccharide. Small amounts of sulphate ester groups and pyruvate 3,6-cyclic acetal groups may be present in agarose. The presence of L-galactose containing agarobiose have been described (structure 2 in Figure 5). These agarobioses can be produced in several variable forms by the different agarophytes depending on the gender and species which depend on their genetic characteristics. Several factors, such as substrate composition, nutrient availability, and hydrodynamic conditions can influence agarobiose production. However, an important factor is the harvesting period, since plants mature with the summer season. Considerable amounts of methyl ether groups are also present. These structural characteristics make agar the least hydrophilic and least water-soluble of the red seaweed polysaccharides, usually only being dissolved in water at $100{ }^{\circ} \mathrm{C}$ or higher temperatures, although preparations that hydrate and dissolve at about $80^{\circ} \mathrm{C}$ are available. Agaroses are the fractions of agar that are, essentially, gel-forming polysaccharides, with 
high molecular weights above 100,000 Daltons and frequently surpass 150,000 Daltons, as well as a low sulphate content usually below $0.15 \%$. The remain agar fractions are essentially agaropectin with lower molecular weight, usually below 20,000 Daltons, typically 14,000 Daltons, containing higher levels of sulphate groups that can sometimes achieve $5 \%$ to $8 \%$. This is far below carrageenan's, which range from $24 \%$ to $53 \%$.
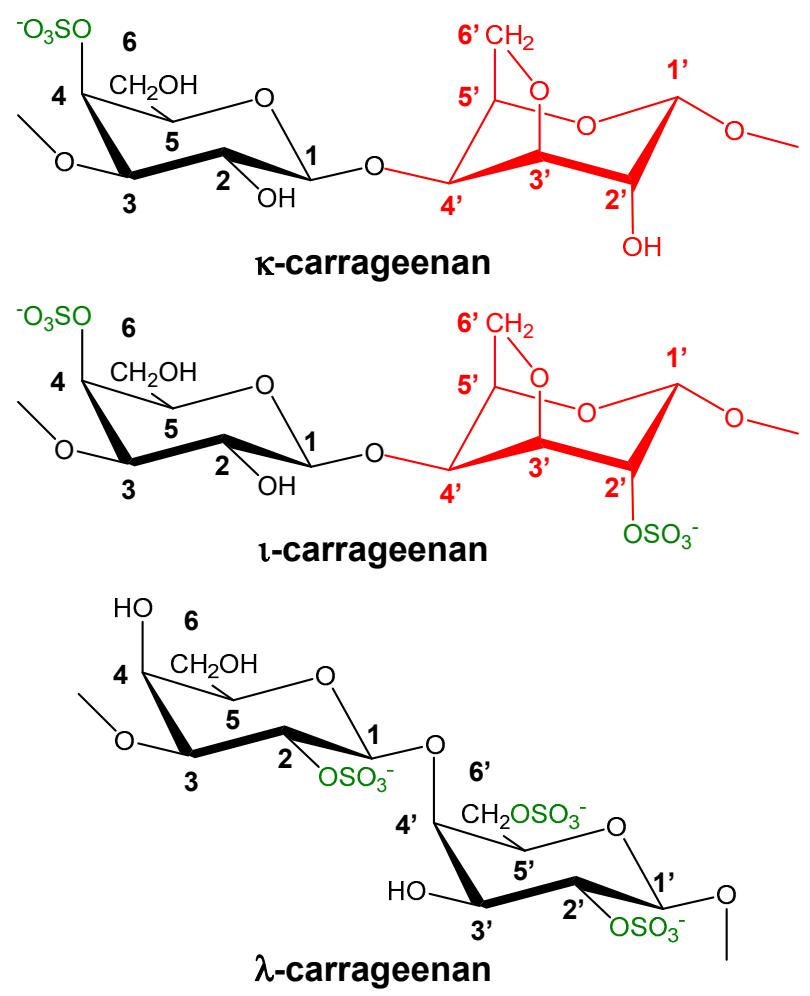

Figure 4. Schematic representation of the structural disaccharide repeating units of $\kappa, \iota$ and $\lambda$ carrageenans.

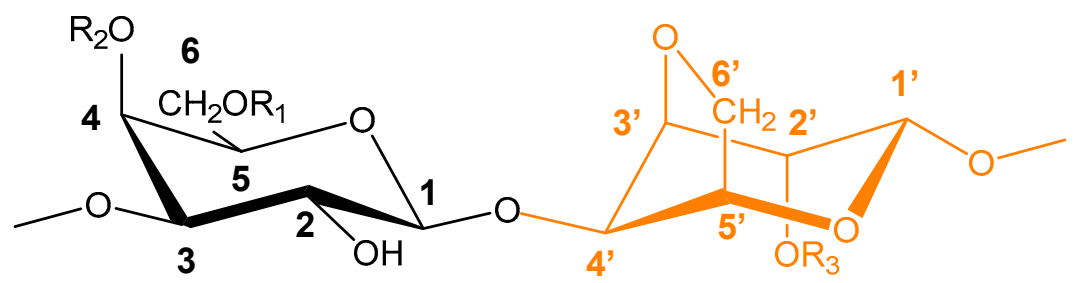

(1)

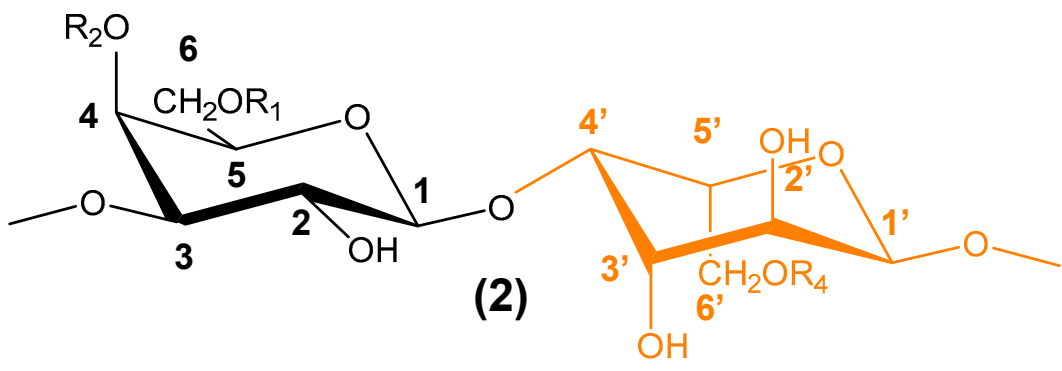

Figure 5. Schematic structures of the agarobiose disaccharides present in agar, (1) 3,6-anhydro- $\alpha$-Lgalactopyranosyl containing agarobiose; (2) L-galactose containing agarobiose. $\mathrm{R}_{1}=\mathrm{H}, \mathrm{CH}_{3}$ or $\mathrm{SO}_{3}{ }^{-}$;

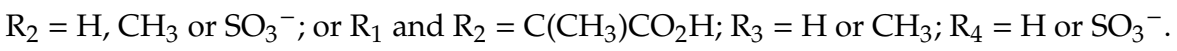


Alginate is another natural algal hydrophilic linear polysaccharide family present in the cell walls of algae, typically obtained from brown seaweed, containing blocks of $(1,4)-\beta$-linked-D-mannuronate (M) and $(1,4)$ - $\alpha$-L-guluronate $(\mathrm{G})$ residues, being also negatively charged at a low $\mathrm{pH}$ [196]. The blocks are composed of consecutive $M$ residues (MMMMM), consecutive $G$ residues (GGGGGG), and alternating $M$ and $G$ residues (GMGMGM) (Figure 6). Alginates extracted from different sources differ in $M$ and $\mathrm{G}$ contents, as well as the length of each block, although alginates with high $\mathrm{G}$ content have far more industrial significance [197]. The molecular weights of commercially available sodium alginates range between 32,000 and $400,000 \mathrm{~g} / \mathrm{mol}$. The viscosity of alginate solutions increases as $\mathrm{pH}$ decreases, and reach a maximum around $\mathrm{pH} 3-3.5$, as carboxylate groups in the alginate backbone become protonated and form hydrogen bonds.

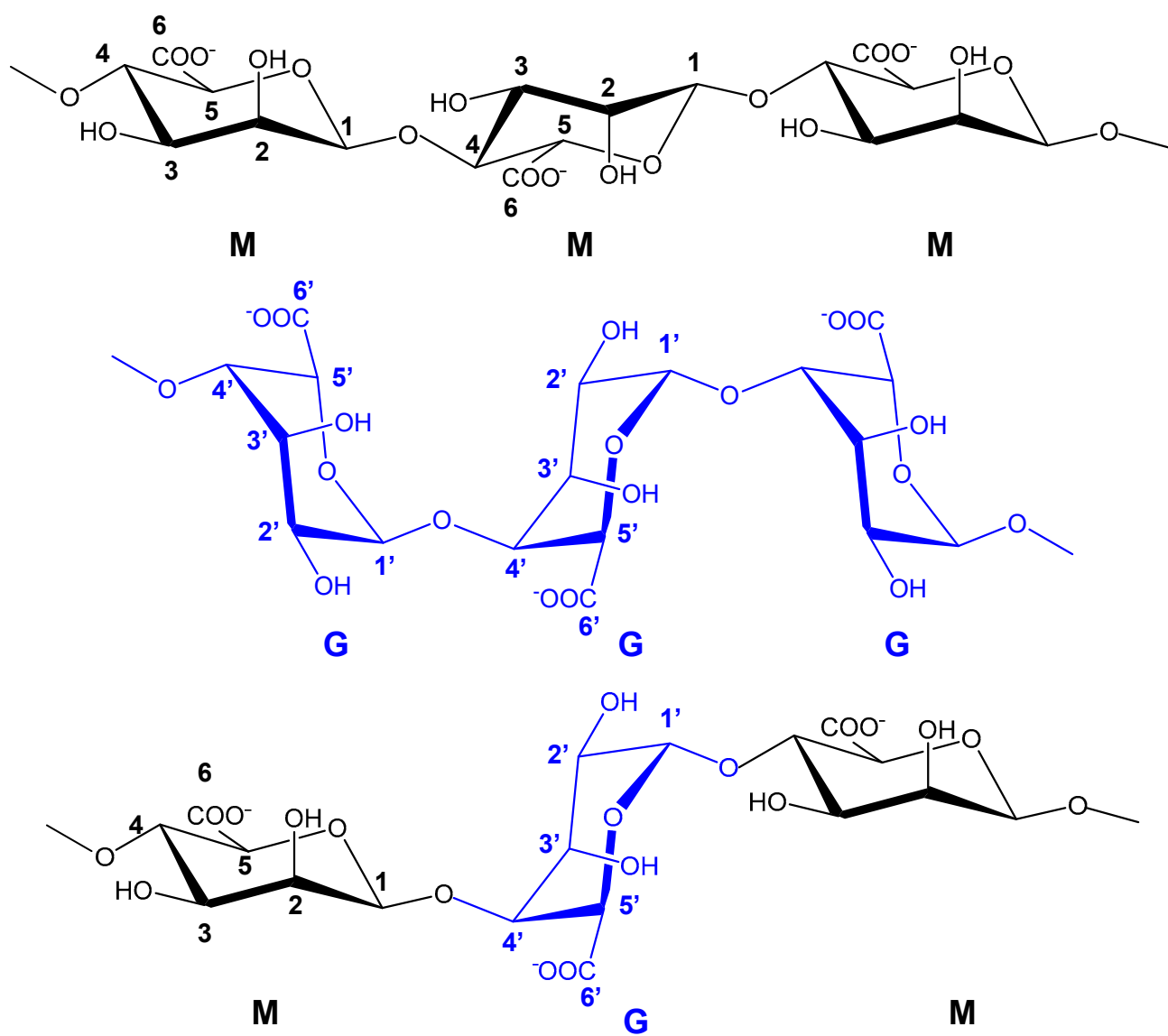

Figure 6. Schematic representation of the M-block, G-block and alternating block in alginate.

Purified carrageenan, dried carrageenophytes, purified alginic acid, and dried alginophytes showed a two-fold higher ability to flocculate and precipitate proteins compared to agar and agarophytes [193]. The better flocculation ability of carrageenan and alginic acid is related to their higher quantity of free negative charges relative to those of agar [193]. Carrageenan applications at different stages of winemaking were studied and the application time proved to be very important for its efficiency. Carrageenan addition before or during fermentation resulted in stable wines, comparable to the wines fined with bentonite [5,192]. However, although less carrageenan is required when applied after fermentation, there is the risk of obtaining wines that fail the heat test due to carrageenan remaining in wine, contributing to haze formation in the heat test and also the wine presenting a lower filterability. It was shown that carrageenan removed the same protein fractions adsorbed by bentonite [193], demonstrating that these polysaccharides might have a greater wine stabilisation capacity without modifying the tannin composition of wines when compared to bentonite [31]. The removal capacity of alginic acid was maximum at protein concentrations less than $50 \mathrm{mg} / \mathrm{L}$; however, carrageenans 
removed proteins at concentrations surpassing $400 \mathrm{mg} / \mathrm{L}$ [193]. Marangon et al. [192], also showed that carrageenan has no deleterious sensory impacts compared to bentonite-treated wines. More recently, Ratnayake et al. [37] studied commercially available carrageenans at different winemaking stages-in grape juice, during fermentation and in wine-to know the efficacy of protein removal and impact on the wine sensory properties. Three different types of carrageenans that were commercially available, $k, l$, and $\lambda$-carrageenans, were used. $k$ - and $k$-/ $/$-carrageenans were effective in stabilising wines in relation to haze formation when measured by the heat test $\left(80^{\circ} \mathrm{C} / 2 \mathrm{~h}, 20^{\circ} \mathrm{C} / 3 \mathrm{~h}\right)$ without negative impacts on the wine's sensory characteristics. Wine filterability and metal ion concentration changed and were dependent on the stage of carrageenan addition in the winemaking process and on the carrageenan structure.

\subsection{Chitin/Chitosan}

Chitin is the most abundant polysaccharide in nature after cellulose. Chitin is generally found as ordered crystalline microfibrils in the structural component of crustaceans and insects and is also found in the cells of fungi and microorganisms. Chitin is a linear polysaccharide composed of $N$-acetyl-D-glucosamine residues linked by $\beta(1 \rightarrow 4)$ linkages (Figure 7). Chitosan is produced commercially by the deacetylation of chitin. It is also a linear polysaccharide composed of randomly distributed $\beta$-(1,4)-linked D-glucosamine residues (deacetylated) and $N$-acetyl-D-glucosamine residues (acetylated). The degree of deacetylation in commercial chitosans is in the range of $60-100 \%$. The amino group in chitosan has a pKa value of about 6.5 . Therefore, chitosan is positively charged and soluble in acidic-to-neutral solutions with a charge density dependent on $\mathrm{pH}$ and the deacetylation extent. Chitin is insoluble in most organic solvents, such as water and dilute acids, due to the high inter- and intramolecular hydrogen bonding. Chitosan is soluble in dilute acidic solutions below $\mathrm{pH}$ 6.0, such as acetic, formic and lactic acids. Both chitin and chitosan are insoluble in neutral water. The chitosan solubility is controlled by the degree of deacetylation and the molecular weight. Although the majority of chitin and chitosan are produced commercially from shellfish waste through chemical treatment, for wine applications, only chitin (Oeno 367-2009 Chitin-Glucan) and chitosan (Oeno 368-2009 Chitosan) obtained from the cell walls of Aspergillus niger are allowed [182,198], with the same maximum limit of $500 \mathrm{~g} / \mathrm{hL}$. Although it shares the same structural features of crustacean chitins, most of the fungal chitin is present in cell walls linked to $\beta 1,3-$ and $\beta 1,6$-glucans [199].

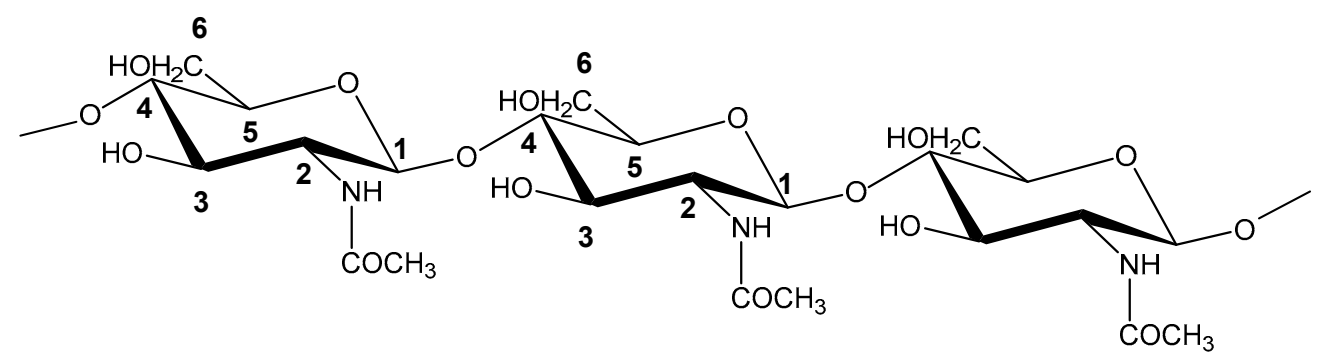

Chitin

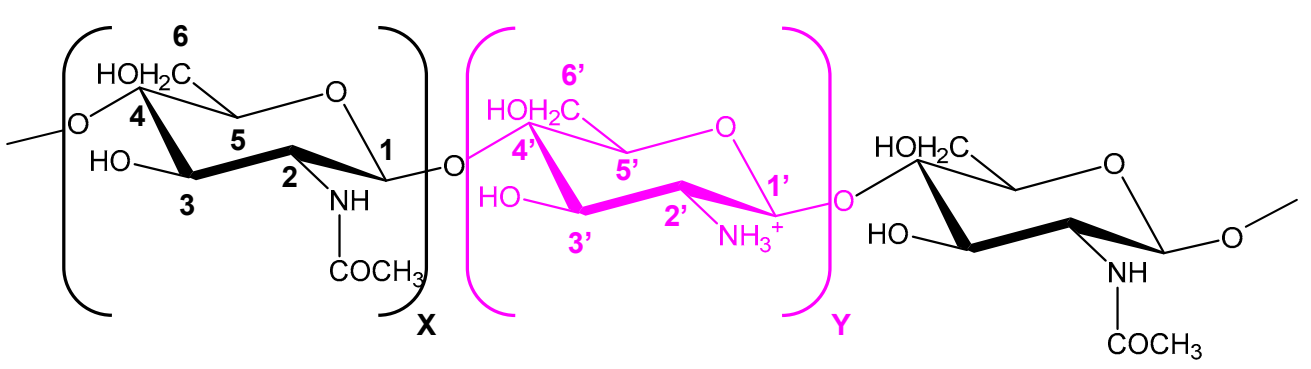

Chitosan

Figure 7. Schematic representation of chitin and chitosan. The relative values of $X$ and $Y$ determined the deamidation degree of the chitosan. 
Studies carried out by Vincenzi et al. [35] showed that chitin can remove specific wine proteins, namely the grape class IV chitinases. The addition of $1 \mathrm{~g} / \mathrm{L}$ of chitin to wine decreased the haze induced by the heat test by $50 \%$, while the addition of $20 \mathrm{~g} / \mathrm{L}$ of chitin decreased the wine haze by almost $80 \%$. This haze reduction was directly related to the removal of the class IV grape chitinases. However, the impact on the wine sensory quality after chitin treatment was not studied. Interestingly, Ndlovu et al. [200] have shown that the use of yeast strains with high cell wall chitin levels can bind chitinases, offering a possibility for reducing wine protein haze formation. On the other hand, Colangelo et al. [36] showed that heat stability of the wines treated with $100 \mathrm{~g} / \mathrm{hL}$ of fungal chitosan-glucan [201] improved in the $55-62{ }^{\circ} \mathrm{C}$ range and this was also due to the specific removal of chitinases.

\subsection{Ultrafiltration}

Membrane ultrafiltration using membranes with diverse molecular weight cut-offs has been studied, aiming to increase wine stability [2]. This technique is based on the ability of membranes with an MW cut-off, ranging between 1-100 kDa, to separate molecules according to their molecular weight. However, ultrafiltration to deal with the white wine turbidity problem has been relatively limited, since the potential of this method in the elimination of other high MW molecules, such as polysaccharides that could associated to the wine quality [202], is not known. Hsu et al. [23] have investigated the effect of ultrafiltration on wine protein stability by using membranes with different $\mathrm{MW}$ cut-offs, ranging between 10-50 kDa. The use of a membrane with an MW cut-off between 10-30 kDa cut-off removed $99 \%$ of wine proteins. However, proteins with an MW between 12.6-30.0 kDa were able to permeate the membrane [24]. These authors have also shown that the white wine treated by ultrafiltration has a high reduction in the yellow colour (A420), total phenols and in aromatic compounds, changing, in this way, the wine's aromatic profile $[24,203,204]$. Additionally, a decrease in the "body" and "mouthfeel" related to the removal of colloids was observed [205]. Gonçalves et al. [202] showed that using an ultrafiltration membrane with an MW cut-off of $100 \mathrm{kDa}$ may be an alternative for wine clarification, in terms of wine quality. However, the efficiency of ultrafiltration depends on wine composition. Moreover, the high cost of equipment and operation and, eventually, the aroma losses associated with this operation, makes the membrane ultrafiltration process unattractive to the wine industry as an alternative for removing unstable proteins.

\subsection{Proteases}

The use of proteases for the hydrolysis of wine proteins [104,206,207], can be an interesting alternative to the previously mentioned stabilisation methods, including the use of bentonite, since it is expected that, comparatively, it has the potential to reduced wine volume loss and the aroma removal observed in the other treatments. However, although some proteases have been used in the beverage industry, papain from papaya [207-209] and bromelain from pineapple [206], they have been tested concerning their effectiveness in the degradation of heat-unstable proteins from white wine. Bromelain showed effectiveness in the degradation of wine proteins (approximately $70 \%$ ) in the model solution as well as in wine, if immobilised in chitosan beads and used in a laboratory-scale stirred reactor $[144,210]$. Therefore, immobilised bromelain on chitosan beads seems an interesting treatment alternative to bentonite for white wine haze stabilisation.

On the other hand, the combination of heat treatment $\left(90^{\circ} \mathrm{C}\right.$ for $\left.1 \mathrm{~min}\right)$ and commercial proteases showed promising results in reducing the incidence of haze formation $[28,104]$, by optimisation of the temperature and time needed for wine protein stabilisation, in an attempt to minimize the negative impact in wine quality. Protease application with flash pasteurisation has been shown to be effective at an industrial scale.

\subsection{Acrylic Acid-Coated Magnetic Nanoparticles}

Acrylic acid-coated magnetic nanoparticles were developed for the selective elimination of pathogenesis-related proteins from wines [211,212], by cation exchange mechanism due to the presence 
of carboxylic acid groups in the modified surface. After these coated magnetic nanoparticles have been placed in heat-unstable wines, the proteins bind to the surface coating and can then be eliminated using a magnet. Even effective in removing most of the wine soluble proteins in the wines, these particles had to be applied to a concentration of $1.66 \%(v / v)$, which corresponds to $13.3 \mathrm{~g} / \mathrm{L}$. This can be associated with the pKa of the carboxylic group existing on the surface of the nanoparticles, which can be very close to the wine $\mathrm{pH}$, affecting its cation exchange capacity. Recently Mierczynska-Vasilev et al. [53] studied the potential of these nanoparticles to be reused in multiple fining and regeneration cycles. The authors verified in the regeneration study that the acrylic acid plasma-coated magnetic nanoparticles, which underwent ten consecutive adsorption-desorption cycles, still retained close to the initial elimination ability for haze proteins from wines when 10\% SDS solution and water were applied for surface regeneration.

\section{Conclusions}

White wine protein instability is linked with many wine external and intrinsic factors, such as wine exposition to high temperatures, wine $\mathrm{pH}$, organic acids, metals, sulphur dioxide levels and phenolic composition and its degree of polymerisation, and some unknown factors ( $X$ factors) leading to wine protein haze formation and precipitation.

Technologies of white wine stabilisation require detailed knowledge about proteins and other wine compounds, as well the interactions that can happen between them. The principal proteins responsible for the haze formation present in wine are the pathogenesis-related proteins, thaumatin-like proteins and chitinases that are resistant to proteolysis during winemaking. Many works have been performed in the last years concerning wine protein stabilisation; however, sodium bentonite remains the most used and efficient method to remove unstable proteins from white wine, with its advantages and disadvantages. Nowadays, the methods to prevent protein haze are not specific enough and are not completely efficient. Controlling the wine haze-formation potential is critical in winemaking, with the heat test method being the most used, allowing for a better prediction.

It is, furthermore, essential to deepen our knowledge regarding the characteristics of wine colloids, where proteins have an important role. The wine protein characterisation, its interactions with other wine components and the effect of other instability factors, are necessary to mitigate this important wine industrial problem. More specific and accurate methods to predict protein instability are necessary for the wine industry. Finally, technology for protein stabilisation (concerning protein instability), with a lower sensory impact and higher specificity, allowing a reduction in the treatment dosage and, consequently, also decreasing the environmental impact of dealing with wine protein instability in the wine industry is still needed.

Funding: This research was funded by the Fundação para a Ciência e Tecnologia (FCT-Portugal) and Operational Competitiveness Programme (COMPETE, Portugal) through the projects Chemistry Research Centre-Vila Real (UIDB/00616/2020) and CIMO (UIDB/00690/2020).

Conflicts of Interest: The authors declare no conflict of interest.

\section{References}

1. Sauvage, F.-X.; Bach, B.; Moutonet, M.; Vernhet, A. Proteins in white wines: Thermo-sensivity and differential adsorption by bentonite. Food Chem. 2010, 118, 26-34. [CrossRef]

2. Ferreira, R.B.; Piçarra-Pereira, M.A.; Monteiro, S.; Loureiro, V.B.; Teixeira, A.R. The wine proteins. Trends Food Sci. Technol. 2002, 12, 230-239. [CrossRef]

3. Dambrouck, T.; Marchal, R.; Marchal-Delahaut, L.; Parmentier, M.; Maujean, A.; Jeandet, P. Immunodetection of proteins from grapes and yeast in a white wine. J. Agric. Food Chem. 2003, 51, 2727-2732. [CrossRef] [PubMed]

4. Waters, E.J.; Alexander, G.; Muhlack, R.; Pocock, K.F.; Colby, C.; O’Neill, B.K.; Høj, P.B.; Jones, P. Preventing protein haze in bottled white wine. Aust. J. Grape Wine Res. 2005, 11, 215-225. [CrossRef] 
5. Marangon, M.; Stockdale, V.J.; Munro, P.; Trethewey, T.; Schulkin, A.; Holt, H.E.; Smith, P.A. Addition of carrageenan at different stages of winemaking for white wine protein stabilization. J. Agric. Food Chem. 2013, 61, 6516-6524. [CrossRef]

6. Waters, E.J.; Wallace, W.; Williams, P.J. Identification of heat-unstable wine proteins and their resistance to peptidases. J. Agric. Food Chem. 1992, 40, 1514-1519. [CrossRef]

7. Høj, P.B.; Tattersall, D.B.; Adams, K.; Pocock, K.F.; Hayasaka, Y.; van Heeswijck, R.; Waters, E. The ‘haze proteins' of wine-A summary of properties, factors affecting their accumulation in grapes, and the amount of bentonite required for their removal from wine. In Proceedings of the ASEV 50th Anniversary Meeting, Seattle, WA, USA, 19-23 June 2000; American Society of Enology and Viticulture: Davis, CA, USA, 2000; pp. 149-154.

8. Boulton, R. The nature of wine proteins. In Proceedings of the Sixth Annual Wine Industry Technology Seminar of the Wine Institute, San Francisco, CA, USA, 1980; pp. 46-58.

9. Batista, L.; Monteiro, S.; Loureiro, V.B.; Teixeira, A.R.; Ferreira, R.B. The complexity of protein haze formation in wines. Food Chem. 2009, 112, 169-177. [CrossRef]

10. Batista, L.; Monteiro, S.; Loureiro, V.B.; Teixeira, A.R.; Ferreira, R.B. Protein haze formation in wines revisited. The stabilizing effect of organic acids. Food Chem. 2010, 122, 1067-1075. [CrossRef]

11. Dufrechou, M.; Poncet-Legrand, C.; Sauvage, F.X.; Vernhet, A. Stability of white wine proteins: Combined effect of $\mathrm{pH}$, ionic strength, and temperature on their aggregation. J. Agric. Food Chem. 2012, 60, 1308-1319. [CrossRef]

12. Pocock, K.F.; Alexander, G.M.; Hayasaka, Y.; Jones, P.R.; Waters, E.J. Sulfate-A candidate for the missing essential factor that is required for the formation of protein haze in white wine. J. Agric. Food Chem. 2007, 55, 1799-1807. [CrossRef]

13. Marangon, M.; Sauvage, F.X.; Waters, E.J.; Vernhet, A. Effects of ionic strength and sulfate upon thermal aggregation of grape chitinases and thaumatin-like proteins in a model system. J. Agric. Food Chem. 2011, 59, 2652-2662. [CrossRef] [PubMed]

14. Peng, Z.; Pocock, K.F.; Waters, E.J.; Francis, I.L.; Williams, P.J. Taste properties of grape (Vitis vinifera) pathogenesis-related proteins isolated from wine. J. Agric. Food Chem. 1997, 45, 4639-4643. [CrossRef]

15. Tabilo-Munizaga, G.; Gordon, T.A.; Villalobos-Carvajal, R.; Moreno-Osorio, L.; Salazar, F.N.; Perez-Won, M.; Acuña, S. Effects of high hydrostatic pressure (HHP) on the protein structure and thermal stability of Sauvignon blanc wine. Food Chem. 2014, 155, 214-220. [CrossRef] [PubMed]

16. Robinson, S.P.; Davies, C. Molecular biology of grape berry ripening. Aust. J. Grape Wine Res. 2000, 6, $175-188$. [CrossRef]

17. Waters, E.J.; Wallace, W.; Tate, M.E.; Williams, P.J. Isolation and partial characterization of a natural haze protective factor from white wine. J. Agric. Food Chem. 1993, 41, 724-730. [CrossRef]

18. Cosme, F.; Ricardo-da-Silva, J.M.; Laureano, O. Interactions between protein fining agents and proanthocyanidins in white wine. Food Chem. 2008, 106, 536-544. [CrossRef]

19. Ribeiro, T.; Fernandes, C.; Nunes, F.M.; Filipe-Ribeiro, L.; Cosme, F. Influence of the structural features of commercial mannoproteins in white wine protein stabilization and chemical and sensory properties. Food Chem. 2014, 159, 47-54. [CrossRef]

20. Lambri, M.; Dordoni, R.; Silva, A.; Faveri, D.M. Comparing the impact of bentonite addiction for both must clarification and wine fining on the chemical profile of wine from Chambave Muscat grapes. Int. J. Food Sci. Technol. 2012, 47, 1-12. [CrossRef]

21. Waters, E.J.; Shirley, N.J.; Williams, P.J. Nuisance proteins of wine are grape pathogenesis related proteins. J. Agric. Food Chem. 1996, 44, 3-5. [CrossRef]

22. Lambri, M.; Dordoni, R.; Silva, A.; Faveri, D.M. Effect of bentonite fining on odor-active compounds in two different white wine styles. Am. J. Enol. Vitic. 2010, 61, 225-233.

23. Hsu, J.-C.; Heatherbell, D.A.; Flores, J.H.; Watson, B.T. Heat-unstable proteins in grape juice and wine. II. Characterization and removal by ultrafiltration. Am. J. Enol. Vitic. 1987, 38, 17-22.

24. Flores, J.H.; Heatherbell, D.A.; McDaniel, M.R. Ultrafiltration of wine: Effect of ultrafiltration on white Riesling and Gewürztraminer wine composition and stability. Am. J. Enol. Vitic. 1990, 41, 207-214.

25. Feuillat, M.; Ferrari, G. Hydrolyse enzymatique des proteins du raisin en vinification. Comptes Rendus des Séances de l'Academie d'Agriculture de France 1982, 68, 1070-1075.

26. Dizy, M.; Bisson, L.F. White wine protein analysis by capillary zone electrophoresis. Am. J. Enol. Vitic. 1999, $50,120-127$. 
27. Francis, I.L.; Sefton, M.A.; Williams, P.J. The sensory effects of pre- or post-fermentation thermal processing on Chardonnay and Semillon wines. Am. J. Enol. Vitic. 1994, 45, 243-251.

28. Pocock, K.F.; Høj, P.B.; Adams, K.S.; Kwiatkowski, M.J.; Waters, E.J. Combined heat and proteolytic enzyme treatment of white wines reduces haze forming protein content without detrimental effect. Aust. J. Grape Wine Res. 2003, 9, 56-63. [CrossRef]

29. Sarmento, M.R.; Oliveira, J.C.; Boulton, R.B. Selection of low swelling materials for protein adsorption from white wines. Int. J. Food Sci. Technol. 2000, 35, 41-47. [CrossRef]

30. Pashova, V.; Guell, C.; López, F. White wine continuous protein stabilization by Packed Column. J. Agric. Food Chem. 2004, 52, 1558-1563. [CrossRef] [PubMed]

31. Salazar, F.N.; Achaerandio, I.; Labbé, M.A.; Güell, C.; López, F. Comparative study of protein stabilisation in white wine using zirconia and bentonite: Physiochemical and wine sensory analysis. J. Agric. Food Chem. 2006, 54, 9955-9958. [CrossRef]

32. Marangon, M.; Lucchetta, M.; Waters, E.J. Protein stabilisation of white wines using zirconium dioxide enclosed in a metallic cage. Aust. J. Grape Wine Res. 2011, 17, 28-35. [CrossRef]

33. Mercurio, M.; Mercurio, V.; Gennaro, B.; Gennaro, M.; Grifra, C.; Langella, A.; Morra, V. Natural zeolites and white wines from Campania region (Southern Italy): A new contribution for solving somo oenological problems. Period Miner. 2010, 79, 95-112.

34. Mierczynska-Vasilev, A.; Wahono, S.K.; Smith, P.-A.; Bindon, K.; Vasilev, K. Using Zeolites To Protein Stabilize White Wines. ACS Sustain. Chem. Eng. 2019, 7, 12240-12247. [CrossRef]

35. Vincenzi, S.; Mosconi, S.; Zoccatelli, G.; Pellegrina, C.D.; Veneri, G.; Chignola, R.; Peruffo, A.; Curioni, A.; Rizzi, C. Development of a new procedure for protein recovery and quantification in wine. Am. J. Enol. Vitic. 2005, 56, 182-187.

36. Colangelo, D.; Torchio, F.; De Faveri, D.M.; Milena, L. The use of chitosan as alternative to bentonite for wine fining: Effects on heat-stability, proteins, organic acids, colour, and volatile compounds in an aromatic white wine. Food Chem. 2018, 264, 301-309. [CrossRef]

37. Ratnayake, S.; Stockdale, V.; Grafton, S.; Munro, P.; Robinson, A.L.; Pearson, W.; McRae, J.M.; Bacic, A. Carrageenans as heat stabilisers of white wine. Aust. J. Grape Wine Res. 2019, 25, 439-450. [CrossRef]

38. Gonzalez-Ramos, D.; Cebollero, E.; Gonzalez, R. A recombinant Saccharomyces cerevisiae strain overproducing mannoproteins stabilizes wine against proteins haze. Appl. Environ. Microb. 2008, 77, 5533-5540. [CrossRef]

39. Zoecklein, B. Bentonite Fining of Juice and Wine; Virginia Cooperative Extension Service: Blacksburg, VA, USA, 1988; Publication 463-014.

40. Santoro, M. Fractionation and characterization of must and wine proteins. Am. J. Enol. Vitic. 1995, 46, 250-254.

41. Anelli, G. The proteins of must. Am. J. Enol. Vitic. 1977, 28, 200-203.

42. Yokotsuka, K.; Yoshii, M.; Aihara, T.; Kushida, T. Isolation and characterization of soluble glycoproteins in red wine. J. Ferment. Technol. 1977, 55, 510-515.

43. Heatherbell, D.; Ngaba, P.; Fombin, B.; Watson, B., Jr.; Garcia, Z.; Flores, J.; Hsu, J. Recent developments in the application of ultrafiltration and protease enzymes to grape juice and wine processing. In Proceedings of the International Symposium on Cool Climate Viticulture and Enology, Eugene, OR, USA, 25-26 June 1984; Heatherbell, D.A., Lombard, P.B., Bodyfelt, F.W., Price, S.F., Eds.; Oregon State University: Eugene, OR, USA, 1985; pp. 418-445.

44. Duncan, B. Varietal differences in white grape protein: Implications for bentonite fining. Aust. N. Z. Wine Ind. J. 1992, 7, 189-193.

45. Dorrestein, E.; Ferreira, R.B.; Laureano, O.; Teixeira, A.R. Electrophorectic and FPLC analysis of soluble proteins in four Portuguese wines. Am. J. Enol. Vitic. 1995, 46, 235-242.

46. Sarmento, M.R.; Oliveiraz, J.C.; Slatner, M.; Boulton, R.B. Effect of Ion-Exchange Adsorption on the Protein Profiles of White Wines. Rev. Agaroquimica y Tecnol. Aliment. 2001, 7, 217-224.

47. Murphey, J.M.; Spayd, J.R.; Powers, J.R. Effect of grape maturation on soluble protein characteristics of Gewürztraminer and white Riesling juice and wine. Am. J. Enol. Vitic. 1989, 40, 199-207.

48. Ough, C.S.; Anelli, G. Zinfandel grape juice fractions and their amino acid makeup as affected by crop level. Am. J. Enol. Vitic. 1979, 30, 8-10.

49. Zoecklein, B. Protein Stability Determination in Juice and Wine; Virginia Cooperative Extension Service: Blacksburg, VA, USA, 1991; Publication 463-015. 
50. Pocock, K.F.; Hayasaha, Y.; McCarthy, M.G.; Waters, E.J. Thaumatin-like proteins and chitinases, the haze-forming proteins of wine, accumulate during ripening of grape (Vitis vinifera) berries and drought stress does not affect the final levels per very maturity. J. Agric. Food Chem. 2000, 48, 1637-1643. [CrossRef]

51. Mesquita, P.R.; Piçarra-Pereira, M.A.; Monteiro, S.; Loureiro, V.B.; Teixeira, A.R.; Ferreira, R.B. Effect of wine composition on protein stability. Am. J. Enol. Vitic. 2001, 52, 324-330.

52. Vincenzi, S.; Polesani, M.; Curioni, A. Removal of specific protein components by chitin enhaces protein stability in a white wine. Am. J. Enol. Vitic. 2005, 56, 246-254.

53. Mierczynska-Vasilev, A.; Boyer, P.; Vasilev, K.; Smith, P.A. A novel technology for the rapid, selective, magnetic removal of pathogenesis-related proteins from wines. Food Chem. 2017, 232, 508-514. [CrossRef]

54. Ferreira, R.B.; Monteiro, S.; Piçarra-Pereira, M.A.; Teixeira, A.R. Engineering grapevine for increased resistance to fungal pathogens without compromising wine stability. Trends Biotechnol. 2004, 22, 168-173. [CrossRef]

55. Moio, L.; Addeo, F. Focalizzazione isoelettrica delle proteine clouding. Vigne Vini 1989, 4, 53-57.

56. Luguera, C.; Moreno-Arribas, V.; Pueyo, E.; Polo, C. Capillary electrophoretic analyses of wine proteins. Modifications during the manufacture of sparkling wines. J. Agric. Food Chem. 1997, 45, 3766-3770. [CrossRef]

57. Okuda, T.; Fukui, M.; Takayanagi, T.; Yokotsuka, K. Characterization of major stable proteins in Chardonnay wine. Food Sci. Technol. Res. 2006, 12, 131-136. [CrossRef]

58. Marangon, M.; Van Sluyter, S.C.; Haynes, P.A.; Waters, E.J. Grape and wine proteins: Their fractionation by hydrophobic interaction chromatography and identification by chromatographic and proteomic analysis. J. Agric. Food Chem. 2009, 57, 4415-4425. [CrossRef] [PubMed]

59. Lowry, O.H.; Rosebrough, N.J.; Farr, A.L.; Randall, R.J. Protein measurement with the folin phenol reagent. J. Biol. Chem. 1951, 193, 265-275. [PubMed]

60. Somers, T.C.; Ziemelis, G. Direct determination of wine proteins. Am. J. Enol. Vitic. 1973, 24, 47-50.

61. Correia, I.; Polo, M.C.; Amigo, L.; Ramos, M. Séparation des protéines des moûts de raisin au moyen de techniques électrophoretiques. Connaissance de la Vigne et du Vin 1988, 22, 1-9. [CrossRef]

62. Gonzalez-Lara, R.; Correa, I.; Polo, M.C.; Martinalvarez, P.J.; Ramos, M. Classification of variety musts by statistical-analysis of their electrophoretic protein pattern. Food Chem. 1988, 34, 103-110. [CrossRef]

63. Moreno-Arribas, M.V.; Cabello, F.; Polo, M.C.; Martin-Alvarez, P.J.; Pueyo, E. Assessment of the native electrophoretic analysis of total grape must proteins for the characterization of Vitis vinifera L. cultivars. J. Agric. Food Chem. 1999, 47, 114-120. [CrossRef]

64. Moretti, R.H.; Berg, H.W. Variability among wines to protein clouding. Am. J. Enol. Vitic. 1965, 16, 69-78.

65. Pueyo, E.; Dizy, M.; Polo, M.C. Varietal differentiation of must and wines by means of protein fraction. Am. J. Enol. Vitic. 1993, 44, 255-260.

66. Bayly, F.C.; Berg, H.W. Grape and wine proteins of white wine varietals. Am. J. Enol. Vitic. 1967, $24,18-32$.

67. Yokotsuka, K.; Ebihara, T.; Sato, T. Comparasion of soluble proteins in juice and wine from koshu grapes. J. Ferment. Bioeng. 1991, 71, 248-253. [CrossRef]

68. Santoro, M.; Faccia, M.; La Notte, E. La frazione proteica di mosti e vini. Nota I: Caratterizzazione elettroforetica. La Rivista di Scienza dell'Alimentazione 1994, 23, 75-80.

69. Esteruelas, M.; Poinsaut, P.; Sieczkowski, N.; Manteau, S.; Fort, M.F.; Canals, J.M.; Zamora, F. Characterization of natural haze protein in Sauvignon white wine. Food Chem. 2009, 113, 28-35. [CrossRef]

70. Waters, E.J.; Wallace, W.; Williams, P.J. Peptidases in winemaking. In Proceedings of the Seventh Australian Wine Industry Technical Conference, Adelaide, Australia, 13-17 August 1990; Williams, P.J., Davidson, D.M., Lee, T.H., Eds.; pp. 186-191.

71. Gonzáles-Lara, R.; Polo, M.C.; Correa, I.; Ramos, M. Características de las proteínas de mostos de uvas de variedades cultivadas en Espanã. Rev. Agroquim. Technol. 1989, 29, 332-339.

72. Dawes, H.; Heatherbell, D.; Fisher, B. Some recent investigations into characterization and removal of unstable proteins in wine. In Proceedings of the 9th International Oenological Symposium, Cascais, Portugal, 24-26 May 1990; pp. 347-369.

73. Lamikanra, O. The proteins of Muscadine grapes. J. Food Sci. 1987, 52, 483-484. [CrossRef]

74. Lamikanra, O.; Inyang, I.D. Temperature influence on Muscadine wine protein characteristics. Am. J. Enol. Vitic. 1988, 39, 113-116.

75. Hsu, J.-C.; Heatherbell, D.A. Isolation and characterization of soluble proteins in grapes, grape juice, and wine. Am. J. Enol. Vitic. 1987, 38, 6-10. 
76. Hsu, J.-C.; Heatherbell, D.A. Heat-unstable proteins in wine. I. Characterization and removal by bentonite fining and heat treatment. Am. J. Enol. Vitic. 1987, 38, 11-16.

77. Dawes, H.; Boyes, S.; Keene, J.; Heatherbell, D.A. Protein instability of wines: Influence of protein isoelectric point. Am. J. Enol. Vitic. 1994, 45, 319-326.

78. Ledoux, V.; Dulau, L.; Dubourdieu, D. Interprétation de l'amélioration de la stabilité protéique des vins au cours de l'élevage sur lies. J. Int. Sci Vigne Vin 1992, 26, 239-251. [CrossRef]

79. Chabreyrie, D.; Chauvet, S.; Guyon, F.; Salagoity, M.H.; Antinelli, J.F.; Medina, B. Characterization and quantification of grape variety by means of shikimic acid concentration and protein fingerprint in still white wines. J. Agric. Food Chem. 2008, 56, 6785-6790. [CrossRef] [PubMed]

80. Dubourdieu, D.; Canal-Liaubères, R.M. Estimation rapide des constituants macromolecullaires de mouts et des vins par chromatographie liquid haute pression (CLHP) de tamisage moleculaire. Connaissace de la Vigne et du Vin 1986, 20, 119-123.

81. Marchal, R.; Bouquelet, S.; Maujean, A. Purification and partial biochemical characterization of glycoproteins in a champenois Chardonnay wine. J. Agric. Food Chem. 1996, 44, 1716-1722. [CrossRef]

82. Canals, J.M.; Arola, L.; Zamora, F. Protein fraction analysis of white wine by FPLC. Am. J. Enol. Vitic. 1998, 49, 383-388.

83. Monteiro, S.; Picarra-Pereira, M.A.; Tanganho, M.C.; Rente, J.P.; Loureiro, V.B.; Teixeira, A.; Ferreira, R.B. Preparation of polyclonal antibodies specific for wine proteins. J. Sci. Food Agric. 1999, 79, 772-778. [CrossRef]

84. Kwon, S.W. Profiling of soluble proteins in wine by nano-highperformance liquid chromatography/tandem mass spectrometry. J. Agric. Food Chem. 2004, 52, 7258-7263. [CrossRef]

85. Baldwin, M.A. Protein identification by mass spectrometry: Issues to be considered. Mol. Cell. Proteom. 2004, 3, 1-9. [CrossRef]

86. Carr, S.; Aebersold, R.; Baldwin, M.; Burlingame, A.; Clause, K.; Nesvizhskii, A. The need for guidelines in publication of peptide and protein identification data: Working Group on Publication Guidelines for Peptide and Protein Identification Data. Mol. Cell. Proteom. 2004, 3, 531-533. [CrossRef]

87. Keller, A.; Nesvizhskii, A.I.; Kolker, E.; Aebersold, R. Empirical statistical model to estimate the accuracy of peptide identifications made by MS/MS and database search. Anal. Chem. 2002, 74, 5383-5392. [CrossRef]

88. Flamini, R.; De Rosso, M. Mass spectrometry in the analysis of grape and wine proteins. Expert Rev. Proteom. 2006, 3, 321-331. [CrossRef] [PubMed]

89. Nunes-Miranda, J.D.; Igrejas, G.; Araujo, E.; Reboiro-Jato, M.; Capelo, J.L. Mass Spectrometry-Based Fingerprinting of Proteins \& Peptides in Wine Quality Control: A Critical Overview. Crit. Rev. Food Sci. Nutr. 2013, 53, 751-759.

90. Monteiro, S.; Piçarra-Pereira, M.A.; Mesquita, P.R.; Loureiro, V.B.; Teixeira, A.; Ferreira, R.B. The wide diversity of structurally similar wine proteins. J. Agric. Food Chem. 2001, 49, 3999-4010. [CrossRef] [PubMed]

91. Carpentieri, A.; Marino, G.; Amoresano, A. Rapid fingerprinting of red wines by MALDI mass spectrometry. Anal. Bioanal. Chem. 2007, 389, 969-982. [CrossRef]

92. Chambery, A.; del Monaco, G.; Di Maro, A.; Parente, A. Peptide fingerprint of high quality Campania white wines by MALDI-TOF mass spectrometry. Food Chem. 2009, 113, 1283-1289. [CrossRef]

93. Cooper, H.J.; Marshall, A.G. Electrospray ionization Fourier transform mass spectrometric analysis of wine. J. Agric. Food Chem. 2001, 49, 5710-5718. [CrossRef]

94. Catharino, R.R.; Cunha, I.B.S.; Fogaca, A.O.; Facco, E.M.P.; Godoy, H.T.; Daudt, C.E.; Eberlin, M.N.; Sawaya, A. Characterization of must and wine of six varieties of grapes by direct infusion electrospray ionization mass spectrometry. J. Mass Spectrom. 2006, 41, 185-190. [CrossRef] [PubMed]

95. Somers, T.C.; Ziemelis, B. The use of gel column analysis in evaluation of bentonite fining procedures. Am. J. Enol. Vitic. 1973, 24, 34-42.

96. Koch, J.; Sajak, E. A review and some studies on grape protein. Am. J. Enol. Vitic. 1959, 18, 114-123.

97. Waters, E.J.; Wallace, W.; Williams, P.J. Heat haze characteristics of fractionated wine proteins. Am. J. Enol. Vitic. 1991, 42, 123-127.

98. Fusi, M.; Mainent, F.; Rizzi, C.; Zoccatelli, G.; Simonato, B. Wine hazing: A predictive assay based on protein and glycoprotein independent recovery and quantification. Food Control. 2010, 21, 830-834. [CrossRef]

99. Esteruelas, M.; Kontoudakis, N.; Gil, M.; Fort, M.F.; Canals, J.M.; Zamora, F. Phenolic compounds present in natural haze protein of Sauvignon white wine. Food Res. Int. 2011, 44, 77-83. [CrossRef] 
100. Falconer, R.; Marangon, M.; Van Sluyter, S.C.; Neilson, K.A.; Chan, C.; Waters, E.J. Thermal stability of thaumatin-like protein, chitinases, and invertase isolated from Sauvignon blanc and Semillon juice and their role in haze formation in wine. J. Agric. Food Chem. 2010, 58, 975-980. [CrossRef] [PubMed]

101. Edreva, A. Pathogenesis-Related proteins: Research progress in the last 15 years. Gen. Appl. Plant. Physiol. 2005, 31, 105-124.

102. Odjakova, M.; Hadjiivanova, C. The complexity of pathogen defense in plants. Bulg. J. Plant. Physiol. 2001, 27, 101-109.

103. Waters, E.J.; Hayasaka, Y.; Tattersall, D.B.; Adams, K.S.; Williams, P.J. Sequence analysis of grape (Vitis vinifera) berry chitinases that cause haze formation in wines. J. Agric. Food Chem. 1998, 46, 4950-4957. [CrossRef]

104. Marangon, M.; Van Sluyter, S.C.; Robinson, E.M.C.; Muhlack, R.A.; Holt, H.E.; Haynes, P.A.; Waters, E.J. Degradation of white wine haze proteins by Aspergillopepsin I and II during juice flash pasteurization. Food Chem. 2012, 135, 1157-1165. [CrossRef]

105. Cilindre, C.; Jegou, S.; Hovasse, A.; Schaeffer, C.; Castro, A.J.; Clement, C.; Van Dorsselaer, A.; Jeandet, P.; Marchal, R. Proteomic approach to identify champagne wine proteins as modified by Botrytis cinerea infection. J. Proteome Res. 2008, 7, 1199-1208. [CrossRef]

106. Marangon, M.; Van Sluyter, S.C.; Waters, E.J.; Menz, R.I. Structure of haze forming proteins in white wines: Vitis vinifera thaumatin-like proteins. PLoS ONE 2014, 9, e113757. [CrossRef]

107. Esteruelas, M.; Poinsaut, P.; Sieczkowski, N.; Manteau, S.; Fort, M.F.; Canals, J.M.; Zamora, F. Comparison of methods for estimating protein stability in white wines. Am. J. Enol. Vitic. 2009, 60, 302-311.

108. Marangon, M.; Van Sluyter, S.C.; Neilson, K.A.; Chan, C.; Haynes, P.A.; Waters, E.J.; Falconer, R.J. Roles of grape thaumatin-like protein and chitinase in white wine haze formation. J. Agric. Food Chem. 2011, 59, 733-740. [CrossRef] [PubMed]

109. Muhlack, R.A.; Waters, E.J.; Lim, A.; O’Neill, B.K.; Colby, C.B. An alternative method for purification of a major thaumatin-like grape protein (VVTL1) responsible for haze formation in white wine. Asia-Pac. J. Chem. Eng. 2007, 2, 70-74. [CrossRef]

110. Ferreira, R.B.; Monteiro, S.; Piçarra-Pereira, M.A.; Tanganho, M.C.; Loureiro, V.B.; Teixeira, A.R. Characterisation of the proteins from grapes and wines by immunological methods. Am. J. Enol. Vitic. 2000, 51, 22-28.

111. Linthorst, H.J.M. Pathogenesis-related proteins of plants. Crit. Rev. Plant. Sci. 1991, 10, 123-150. [CrossRef]

112. Dufrechou, M.; Vernhet, A.; Roblin, P.; Sauvage, F.X.; Poncet-Legrand, C. White wine proteins: How does the $\mathrm{pH}$ affect their conformation at room temperature? Langmuir 2013, 29, 10475-10482. [CrossRef]

113. Tattersall, D.B.; Pocock, K.F.; Hayasaka, Y.; Adams, K.; Van Heeswijck, R.; Waters, E.J.; Høj, P.B. Pathogenesis related proteins-Their accumulation in grapes during berry growth and their involvement in white wine heat instability. Current knowledge and future perspectives in relation to winemaking practices. Mol. Biol. Biotechnol. Grapevine 2001, 183-201. [CrossRef]

114. Pocock, K.F.; Hayasaka, Y.; Peng, Z.; Williams, P.J.; Waters, E.J. The effect of mechanical harvesting and long-distance transport on the concentration of haze-forming proteins in grape juice. Aust. J. Grape Wine Res. 1998, 4, 23-29. [CrossRef]

115. Van Sluyter, S.C.; McRae, J.M.; Falconer, R.J.; Smith, P.A.; Bacic, A.; Waters, E.J.; Marangon, M. Wine protein haze: Mechanisms of formation and advances in prevention. J. Agric. Food Chem. 2015, 63, 4020-4030. [CrossRef]

116. Gazzola, D.; Van Sluyter, S.C.; Curioni, A.; Waters, E.J.; Marangon, M. Roles of proteins, polysaccharides, and phenolics in haze formation in white wine via reconstitution experiments. J. Agric. Food Chem. 2012, 60, 10666-10673. [CrossRef]

117. D'Amato, A.; Fasoli, E.; Kravchuk, A.V.; Righetti, P.G. Mehercules, adhuc Bacchus! The Debate on Wine Proteomics Continues. J. Proteome Res. 2011, 10, 3789-3801. [CrossRef]

118. Lambri, M.; Dordoni, R.; Giribaldi, M.; Violetta, M.R.; Giuffrida, M.G. Heat-unstable protein removal by different bentonite labels in white wines. LWT-Food Sci. Technol. 2012, 46, 460-467. [CrossRef]

119. Sarmento, M.R.; Oliveira, J.C.; Slatner, M.; Boulton, R.B. Influence of intrinsic factors on conventional wine protein stability tests. Food Control 2000, 11, 423-432. [CrossRef]

120. Marangon, M.; Vincenzi, S.; Lucchetta, M.; Curioni, A. Heating and reduction affect the reaction with tannins of wine protein fractions differing in hydrophobicity. Anal. Chim. Acta 2010, 660, 110-118. [CrossRef] [PubMed] 
121. Waters, E.J.; Peng, Z.; Pocock, K.F.; Williams, P.J. Proteins in white wine, II: Their resistance to proteolysis is not due to either phenolic association or glycosylation. Aust. J. Grape Wine Res. 1995, 1, 94-99. [CrossRef]

122. Siebert, K.J.; Troukhanova, N.V.; Lynn, P.Y. Nature of polyphenol-protein interactions. J. Agric. Food Chem. 1996, 44, 80-85. [CrossRef]

123. Yokotsuka, K.; Singleton, V.L. Interactive precipitation between phenolic fractions and peptides in wine-like model solutions: Turbidity, particle size, and residual content as influenced by $\mathrm{pH}$, temperature and peptide concentration. Am. J. Enol. Vitic. 1995, 46, 329-338.

124. Besse, C.; Clark, A.; Scollary, G. Investigation of the role of total and free copper in protein in haze formation. Aust. Grapegrow. Winemak. 2000, 437, 19-20.

125. Pellerin, P.; Waters, E.J.; Brillouet, J.-M.; Moutounet, M. Effet of polysaccharides sur la formation de trouble protéique dans un vin blanc. J. Int. Sci. Vigne Vin 1994, 24, 13-18. [CrossRef]

126. Chagas, R.; Lourenço, A.M.; Monteiro, S.; Ferreira, R.B.; Ferreira, L.M. Is caffeic acid, as the major metabolite present in Moscatel wine protein haze hydrolysate, involved in protein haze formation? Food Res. Int. 2017, 98, 103-109. [CrossRef]

127. Chagas, R.; Ferreira, L.M.; Laia, C.A.T.; Monteiro, S.; Ferreira, R.B. The challenging $\mathrm{SO}_{2}$-mediated chemical build-up of protein aggregates in wines. Food Chem. 2016, 192, 460-469. [CrossRef]

128. de Bruijn, J.; Loyola, C.; Arumi, J.L.; Martinez, J. Effect of non-protein factors on heat stability of Chilean Sauvignon Blanc wines. Chil. J. Agric. Res. 2014, 74, 490-496. [CrossRef]

129. McRae, J.M.; Barricklow, V.; Pocock, K.F.; Smith, P.A. Predicting protein haze formation in white wines. Aust. J. Grape Wine Res. 2018, 24, 504-511. [CrossRef]

130. Dupin, I.V.S.; McKinnon, B.M.; Ryan, C.; Boulay, M.; Markides, A.J.; Jones, G.P.; Williams, P.J.; Waters, E.J. Saccharomyces cerevisiae mannoproteins that protect wine from protein haze: Their release during fermentation and lees contact and a proposal for their mechanism of action. J. Agric. Food Chem. 2000, 48, 3098-3105. [CrossRef] [PubMed]

131. Jaeckels, N.; Meier, M.; Dietrich, H.; Will, F.; Decker, H.; Fronk, P. Influence of polysaccharides on wine protein aggregation. Food Chem. 2016, 200, 38-45. [CrossRef] [PubMed]

132. Boulton, R.B.; Singleton, V.L.; Bisson, L.F.; Kunkee, R.E. Principles and Practices of Winemaking; Chapman \& Hall: New York, NY, USA, 1996.

133. Toland, T.M.; Fugelsang, K.C.; Muller, C.J. Methods for estimating protein instability in white wines: A comparison. Am. J. Enol. Vitic. 1996, 47, 111-112.

134. Pocock, K.F.; Waters, E.J. Protein haze in bottled white wines: How well do stability tests and bentonite fining trials predict haze formation during storage and transport? Aust. J. Grape Wine Res. 2006, 12, 212-220. [CrossRef]

135. Ribéreau-Gayon, P.; Glories, Y.; Maujean, A.; Dubourdieu, D. Handbook of Enology. Volume 2: The Chemistry of Wine Stabilization and Treatments; John Wiley and Sons Inc.: Hoboken, NJ, USA, 2006.

136. Berg, H.W.; Akiyoshi, M. Determination of protein stability in wine. Am. J. Enol. Vitic. 1961, 12, 107-110.

137. Pocock, K.; Rankine, B.C. Heat test for detecting protein instability in wine. Aust. Wine Brew. Spirit Rev. 1973, $91,42-43$.

138. Rankine, B.C.; Pocock, K.F. A new method for detecting protein instability in white wines. Aust. Wine Brew. Spirit Rev. 1971, 89, 61.

139. Mesrob, B.; Gorinova, N.; Tsakov, D. Characterization of the electrical properties and molecular weights of the proteins in white wines. Nahrung 1983, 27, 727-733. [CrossRef]

140. Gonzalez-Ramos, D.; Quiro, M.; Gonzalez, R. Three different targets for the genetic modification of wine yeast strains resulting in improved effectiveness of bentonite fining. J. Agric. Food Chem. 2009, 57, 8373-8378. [CrossRef] [PubMed]

141. Salazar, F.N.; Marangon, M.; Labbé, M.; Lira, E.; Rodríguez-Bencomo, J.J.; López, F. Comparative study of sodium bentonite and sodium-activated bentonite fining during white wine fermentation: Its effect on protein content, protein stability, lees volume, and volatile compounds. Eur. Food Res. Technol. 2017, 243, 2043-2054. [CrossRef]

142. Meier, M.; Jaeckels, N.; Tenzer, S.; Stoll, M.; Decker, H.; Fronk, P.; Dietrich, H.; Will, F. Impact of drought stress on concentration and composition of wine proteins in Riesling. Eur. Food Res. Technol. 2016, 242, 1883-1891. [CrossRef]

143. Vincenzi, S.; Marangon, M.; Tolin, S.; Curioni, A. Protein evolution during the early stages of white winemaking and its relations with wine stability. Aust. J. Grape Wine Res. 2011, 17, 20-27. [CrossRef] 
144. Benucci, I.; Lombardelli, C.; Cacciotti, I.; Liburdi, K.; Nanni, F.; Esti, M. Chitosan beads from microbial and animal sources as enzyme supports for wine application. Food Hydrocoll. 2016, 61, 191-200. [CrossRef]

145. Dubourdieu, D.; Serrano, M.; Vannier, A.C.; Ribéreau-Gayon, P. Étude comparée des tests de stabilité protéique. Connaiss. Vigne Vin 1988, 22, 261-273. [CrossRef]

146. Gabrielli, M.; Fracassetti, D.; Tirelli, A. Release of phenolic compounds from corks toppers and its effect on protein-haze. Food Control 2016, 62, 330-336. [CrossRef]

147. Giese, E.C.; Ocaña, M.C.; Simancas, N.B.; Briones Pérez, A.I.; Decker, R.F.H.; Barbosa, A.M. Evaluation of the components released by wine yeast strains on protein haze formation in white wine. Orbital Electron. J. Chem. 2016, 8, 307-313. [CrossRef]

148. Yokotsuka, K.; Nozaki, K.; Kushida, T. Turbidity formation caused by interaction of must proteins with wine tannins. J. Ferment. Technol. 1983, 61, 413-416.

149. Lehninger, A.L. Biochemistry, 2th ed.; Worth Publishers: New York, NY, USA, 1981.

150. Versari, A.; Laghi, L.; Thorngate, J.H.; Boulton, R.B. Prediction of colloidal stability in white wines using infrared spectroscopy. J. Food Eng. 2011, 104, 239-245. [CrossRef]

151. Dulau, L. Recherches sur les protÉines Responsables de la Casse Protéique des vins Blancs Secs. Ph.D. Thesis, Universit'e de Bordeaux II, Bordeaux, France, 1990.

152. Paetzold, M.; Dulau, L.; Dubourdieu, D. Fractionnement et caract'erisation des glycoproteins dans les mo^uts de raisins blancs. J. Int. Sci. Vigne Vin 1990, 24, 13-28.

153. Kleijn, W.B.; Oster, J.D. A Model of Clay Swelling and Tactoid Formation. Clay Clay Miner. 1982, 30, 383-390. [CrossRef]

154. Catarino, S.; Madeira, M.; Monteiro, F.; Rocha, F.; Curvelo-Gacia, A.S.; Bruno de Sousa, R. Effect of bentonite characteristics on the elemental composition of wine. J. Agric. Food Chem. 2008, 56, 158-165. [CrossRef] [PubMed]

155. Marchal, R.; Barret, J.; Maujean, A. Relations entre les caractéristiques physic-chimiques d'une bentonite et son pouvoir d'adsorption. J. Int. Sci. Vigne Vin 1995, 29, 27-42.

156. Segad, M.; Jonsson, B.; Akesson, T.; Cabane, B. Ca/Na Montmorillonite: Structure, Forces and Swelling Properties. Langmuir 2010, 26, 5782-5790. [CrossRef] [PubMed]

157. Blade, W.; Boulton, R. Adsorption of protein by bentonite in a model wine solution. Am. J. Enol. Vitic. 1988, 39, 193-199.

158. Lagace, L.S.; Bisson, L.F. Survey of yeast acid proteases for effectiveness of wine haze reduction. Am. J. Enol. Vitic. 1990, 41, 147-155.

159. Jaeckels, N.; Tenzer, S.; Meier, M.; Will, F.; Dietrich, H.; Decker, H.; Fronk, P. Influence of bentonite fining on protein composition in wine. LWT-Food Sci. Technol. 2017, 75, 335-343. [CrossRef]

160. Achaerandio, I.; Pachova, V.; Güell, C.; López, F. Protein adsorption by bentonite in a white wine model solution: Effect of protein molecular weight and ethanol concentration. Am. J. Enol. Vitic. 2001, 52, 122-126.

161. Moio, L.; Ugliano, M.; Gambuti, A.; Genovese, A.; Piombino, P. Influence of clarification treatment on concentrations of selected free varietal aroma compounds and glycoconjugates in Falanghina (Vitis vinifera L.) must and wine. Am. J. Enol. Vitic. 2004, 55, 7-12.

162. Armada, L.; Falqué, E. Repercussion of the clarification treatment agents before the alcoholic fermentation on volatile composition of white wines. Eur. Food Res. Technol. 2007, 225, 553-558. [CrossRef]

163. Vincenzi, S.; Panighel, A.; Gazzola, D.; Flamini, R.; Curioni, A. Study of Combined Effect of Proteins and Bentonite Fining on the Wine Aroma Loss. J. Agric. Food Chem. 2015, 63, 2314-2320. [CrossRef] [PubMed]

164. Lira, E.; Rodríguez-Bencomo, J.J.; Salazar, F.N.; Orriols, I.; Fornos, D.; López, F. Impact of Bentonite Additions during Vinification on Protein Stability and Volatile Compounds of Albariño Wines. J. Agric. Food Chem. 2015, 63, 3004-3011. [CrossRef]

165. Vela, E.; Hernández-Orte, P.; Castro, E.; Ferreira, V.; Lopez, R. Effect of Bentonite Fining on Polyfunctional Mercaptans and Other Volatile Compounds in Sauvignon blanc Wines. Am. J. Enol. Vitic. 2017, 68, 30-38. [CrossRef]

166. Burin, V.M.; Caliari, V.; Bordignon-Luiz, M.T. Nitrogen compounds in must and volatile profile of white wine: Influence of clarification process before alcoholic fermentation. Food Chem. 2016, 202, 417-425. [CrossRef]

167. Ewart, A.J.W.; Phipps, G.J.; Iland, P.G. Bentonite additions to wine: Before, during or after fermentation? Aust. N. Z. Grapegrow. Winemak. 1980, 196, 46-47. 
168. Lira, E.; Salazar, F.N.; Rodríguez-Bencomo, J.J.; Vincenzi, S.; Curioni, A.; López, F. Effect of using bentonite during fermentation on protein stabilisation and sensory properties of white wine. Int. J. Food Sci Technol. 2014, 49, 1070-1078. [CrossRef]

169. Dordoni, R.; Colangelo, D.; Giribaldi, M.; Giuffrida, M.G.; De Faveri, D.M.; Lambri, M. Effect of Bentonite Characteristics on Wine Proteins, Polyphenols, and Metals under Conditions of Different pH. Am. J. Enol. Vitic. 2015, 66, 518-530. [CrossRef]

170. Liu, A.; Nyavor, K.; Ankumah, R. Structural and adsorptive properties of Ba or Mg oxide modified zirconia. J. Colloid Interface Sci. 2005, 284, 66-70. [CrossRef] [PubMed]

171. Salazar, F.N.; Zamora, F.; Canals, J.M.; Lopez, F. Protein stabilization in sparkling base wine using zirconia and bentonite: Influence on the foam parameters and protein fractions. J. Int. Sci. Vigne Vin 2010, 44, 51-58.

172. Wyss, C.; Cuénat, P. Stabilisation tartrique des vins par traitement aux zéolithes. Rev. Suisse Vitic. Arboric. Hortic. 2005, 37, 341-347.

173. Powers, J.R.; Nagel, C.W.; Weller, K. Protein removal from a wine by immobilized grape proanthocyanidins. Am. J. Enol. Vitic. 1988, 39, 117-120.

174. Gonçalves, F.; Heyraud, A.; Pinho, M.N.; Rinaudo, M. Characterization of white wine mannoproteins. J. Agric. Food Chem. 2002, 50, 6097-6101. [CrossRef] [PubMed]

175. Klis, F.M.; Mol, P.; Hellingwerf, K.; Brul, S. Dynamics of cell wall structure in Saccharomyces cerevisiae. FEMS Microbiol. Rev. 2002, 26, 239-256. [CrossRef]

176. Rodrigues, A.; Ricardo-Da-Silva, J.M.; Lucas, C.; Laureano, O. Effect of commercial mannoproteins on wine colour and tannins stability. Food Chem. 2012, 131, 907-914. [CrossRef]

177. Rodrigues, A.; Ricardo-Da-Silva, J.M.; Lucas, C.; Laureano, O. Influence of fining and tartaric Stabilisation Procedures on white wine mannoprotein content. S. Afr. J. Enol. Vitic. 2012, 33, 88-94. [CrossRef]

178. Strahl-Bolsinger, S.; Gentzsch, M.; Tanner, W. Protein O-mannosylation. Biochim. Biophys. Acta 1999, 1426, 297-307. [CrossRef]

179. Waters, E.J.; Pellerin, P.; Brillouet, J.-M. A Saccharomyces mannoprotein that protects wine from protein haze. Carbohydr. Polym. 1994, 23, 185-191. [CrossRef]

180. Hernández, L.M.; Ballou, L.; Alvarado, E.; Gillece-Castro, B.L.; Burlingame, A.L.; Ballou, C.E. A new Saccharomyces cerevisiae mnn mutant N-linked oligosaccharide structure. J. Biol. Chem. 1989, 264, 11849-11856.

181. Varki, A.; Cummings, R.D.; Aebi, M.; Packer, N.H.; Seeberger, P.H.; Esko, J.D.; Stanley, P.; Hart, G.; Darvill, A.; Kinoshita, T.; et al. Symbol Nomenclature for Graphical Representation of Glycans. Glycobiology 2015, 25, 1323-1324. [CrossRef]

182. OIV. Codex Oenologique International; Internationale de la Vigne et du Vin: Paris, France, 2009.

183. Peat, S.; Whelan, W.J.; Edwards, T.E. 6. Polysaccharide of baker's yeast. Part IV. Mannan. J. Chem. Soc. 1961, 28-35. [CrossRef]

184. Moine-Ledoux, V.; Dubourdieu, D. Rôle des mannoprotéines de levures vis-à-vis de la stabilisation tartrique des vins. Bulletin Organization de la vigne et du vin 2002, 75, 471-482.

185. Gonzales-Ramos, D.; Gonzalez, R. Genetic determinants of the release of mannoproteins of enological interest by Saccharomyces cerevissiae. J. Agric Food Chem. 2006, 54, 9411-9416. [CrossRef] [PubMed]

186. Waters, E.J.; Pellerin, P.; Brillouet, J.M. A wine arabonogalactan-proteins that reduces heat-induced wine protein haze. Biosci. Biotechnol. Biochem. 1994, 58, 43-48. [CrossRef]

187. Escot, S.; Feulliat, M.; Dulau, L.; Charpentier, C. Release of polysaccharides by yeasts and the influence of released polysaccharides on colour stability and wine astringency. Aust. J. Grape Wine Res. 2001, 7, 153-159. [CrossRef]

188. Vidal, S.; Francis, L.; Williams, P.; Kwiatkowski, M.; Gawel, R.; Cheynier, V.; Waters, E. The mouth-feel properties of polysaccharides and anthocyanins in a wine like medium. Food Chem. 2004, 85, 519-525. [CrossRef]

189. Guadalupe, Z.; Martínez, L.; Ayestarán, B. Yeast mannoproteins in red winemaking. Effect on polysaccharide, polyphenolic and colour composition. Am. J. Enol. Vitic. 2010, 61, 191-200.

190. Guadalupe, Z.; Palacios, A.; Ayestarán, B. Maceration enzymes and mannoproteins: A possible strategy to increase colloidal stability and colour extraction in red wines. J. Agric. Food Chem. 2007, 55, 4854-4862. [CrossRef]

191. Moine-Ledoux, V.; Dubourdieu, D. An invertase fragment responsible for improving the protein stability of dry white wines. J. Sci. Food Agric. 1999, 79, 537-543. [CrossRef] 
192. Marangon, M.; Lucchetta, M.; Duan, D.; Stockdale, V.J.; Hart, A.; Rogers, P.J.; Waters, E.J. Protein removal from a Chardonnay juice by addition of carrageenan and pectin. Aust. J. Grape Wine Res. 2012, 18, 194-202. [CrossRef]

193. Cabello-Pasini, A.; Victoria-Cota, N.; Macias-Carranza, V.; Hernandez-Garibay, E.; Muñiz-Salazar, R. Clarification of wines using polysaccharides extracted from seaweeds. Am. J. Enol. Vitic. 2005, 56, 52-59.

194. Campo, V.L.; Kawano, F.F.; Silva, D.B., Jr.; Carvalho, I. Carrageenans: Biological properties, chemical modifications and structural analysis. Carbohydr. Polym. 2009, 77, 167-180. [CrossRef]

195. Guangling, J.; Guangli, Y.; Junzeng, Z.; Ewart, H.S. Chemical structures and bioactivities of sulfated polysaccharides from marine algae. Mar. Drugs 2011, 9, 196-233.

196. Sime, W. The practical utilization of alginates in food gelling systems. In Gums and Stabilizers for the Food Industry; Phillips, G., Ed.; Pergamon Press: Oxford, UK, 1984; pp. 177-188.

197. Usov, A.I.; Zelinski, N.D. Chemical structures of algal polysaccharides. In Functional Ingredients from Algae for Foods and Nutraceuticals; Domínguez, H., Ed.; Elsevier Science: Cambridge, UK, 2013; pp. 45-49.

198. European Union (EU). Commission regulation (EU) 53/2011 of 21 January 2011. Available online: https://eurlex.europa.eu/LexUriServ/LexUriServ.do?uri=OJ:L:2011:019:0001:0006:EN:PDF (accessed on 22 January 2011).

199. Arroyo, J.; Farkaš, V.; Sanz, A.B.; Cabib, E. Strengthening the fungal cell wall through chitin-glucan cross-links: Effects on morphogenesis and cell integrity. Cell Microbiol. 2016, 18, 1239-1250. [CrossRef] [PubMed]

200. Ndlovu, T.; Divol, B.; Bauera, F.F. Yeast Cell Wall Chitin Reduces Wine Haze Formation. Appl. Environ. Microbiol. 2018, 84, e00668-1. [CrossRef]

201. Filipe-Ribeiro, L.; Cosme, F.; Nunes, F.M. Reducing the negative sensory impact of volatile phenols in red wine with different chitosans: Effect of structure on efficiency. Food Chem. 2018, 242, 591-600. [CrossRef]

202. Gonçalves, F.; Fernandes, C.; Pinho, M.N. White wine clarification by micro/ ultrafiltration: Effect of remover colloids in tartaric stability. Sep. Purif. Technol. 2001, 22-23, 423-429. [CrossRef]

203. Miller, G.C.; Amon, J.M.; Gibson, R.L.; Simpson, R.F. Loss of wine aroma attributable to protein stabilization with bentonite or ultrafiltration. Aust. N. Z. Grapegrow. Winemak. 1985, 256, 46-50.

204. Voilley, A.; Lamer, C.; Dubois, P.; Feuillat, M. Influence of macromolecules and tratments on the behavior of aroma compounds in a model wine. J. Agric. Food Chem. 1990, 38, 248-251. [CrossRef]

205. Konja, G.; Clauss, E.; Kovacic, Z.; Pozderovic, A. The influence of ultrafiltration on the chemical composition and sensory characteristics of white and rose wine. Chem. Biochem. Eng. Q. 1988, 2, 235-241.

206. Benucci, I.; Esti, M.; Liburdi, K. Effect of free and immobilised stem bromelain on protein haze in white wine. Aust. J. Grape Wine Res. 2014, 20, 347-352. [CrossRef]

207. Benucci, I.; Esti, M.; Liburdi, K. Effect of wine inhibitors on the proteolytic activity of papain from Carica papaya L. Latex. Biotechnol. Prog. 2015, 31, 48-54. [CrossRef] [PubMed]

208. Rehmanji, M.; Gopal, C.; Mola, A. Beer stabilization technology-Clearly a matter of choice. Master Brew. Assoc. Am. Technol. Q. 2005, 42, 332-338.

209. Esti, M.; Benucci, I.; Lombardelli, C.; Liburdi, K.; Garzillo, A.M.V. Papain from papaya (Carica papaya L.) fruit and latex: Preliminary characterization in alcoholic-acidic buffer for wine application. Food Bioprod. Process. 2013, 91, 595-598. [CrossRef]

210. Benucci, I.; Lombardelli, C.; Liburdi, K.; Acciaro, G.; Zappino, M.; Esti, M. Immobilised native plant cysteine proteases: Packed-bed reactor for white wine protein stabilisation. J. Food Sci. Technol. 2016, 53, 1130-1139. [CrossRef] [PubMed]

211. Mierczynska-Vasilev, A.; Mierczynskic, P.; Maniukiewiczc, W.; Visalakshanb, R.M.; Vasilevd, K.; Smith, P.A. Magnetic separation technology: Functional group efficiency in the removal of haze-forming proteins from wines. Food Chem. 2019, 275, 154-160. [CrossRef]

212. Mierczynska-Vasilev, A.; Qi, G.; Smith, P.; Bindon, K.; Vasilev, K. Regeneration of Magnetic Nanoparticles Used in the Removal of Pathogenesis-Related Proteins from White Wines. Foods 2020, 9, 1. [CrossRef]

(C) 2020 by the authors. Licensee MDPI, Basel, Switzerland. This article is an open access article distributed under the terms and conditions of the Creative Commons Attribution (CC BY) license (http://creativecommons.org/licenses/by/4.0/). 